\title{
Description of a new species of Spiralothelphusa Bott, 1968, and redescription of Spiralothelphusa wuellerstorfi (Heller, 1862) (Decapoda: Brachyura: Gecarcinucidae)
}

\author{
Sameer K. PATI ${ }^{\oplus 1, *}$, Sudipta MANDAL $^{\oplus 2} \&$ Deepa JAISWAL ${ }^{\oplus 3}$ \\ ${ }^{1}$ Zoological Survey of India, Western Regional Centre, Akurdi, Pune 411 044, India. \\ ${ }^{2,3}$ Zoological Survey of India, Freshwater Biology Regional Centre, Attapur, \\ Hyderabad 500 048, India. \\ ${ }^{*}$ Corresponding author: sameer_pati@yahoo.co.in \\ ${ }^{2}$ Email: sudiptam531@gmail.com \\ 33Email: deepajzsi@gmail.com \\ ${ }^{1}$ urn:1sid:zoobank.org:author:7A1FD506-7C36-493B-9C42-9E2B733E022C \\ ${ }^{2}$ urn:1sid:zoobank.org:author:A1C879AB-3812-4402-B612-08D96F0FD7E7 \\ ${ }^{3}$ urn:1sid:zoobank.org:author:FBC64DAF-7378-4F9A-BCEA-5D6805288AA2
}

\begin{abstract}
A new species of the gecarcinucid freshwater crab genus, Spiralothelphusa Bott, 1968, is described from the Andhra Pradesh State of South India, with supporting data from mitochondrial cytochrome c oxidase subunit I. This brings the number of known species of Spiralothelphusa to seven, five from India and two from Sri Lanka. The identity of $S$. wuellerstorfi (Heller, 1862) has remained uncertain because the former lectotype designation was not clear. Bott (1968), while designating a male lectotype of $S$. wuellerstorf from the Naturhistorisches Museum Wien, Vienna, Austria, had neither stated the catalogue number nor the size of the specimen. It is now difficult to trace the particular lectotype among several paralectotypes of the depository. A new lectotype is, therefore, designated herein for $S$. wuellerstorfi, and the species is redescribed. The new species, $S$. andhra sp. nov., has morphological affinities with $S$. wuellerstorfi, but can be distinguished from the latter species by the shape of the male telson and outer margin of the non-twisted portion of the male first gonopod. Phylogenetic analyses of the molecular data also corroborate their separation. An illustrated identification key is provided for the species of Spiralothelphusa.
\end{abstract}

Keywords. Taxonomy, Crustacea, freshwater crabs, mt COI DNA, South India.

Pati S.K., Mandal S. \& Jaiswal D. 2022. Description of a new species of Spiralothelphusa Bott, 1968, and redescription of Spiralothelphusa wuellerstorfi (Heller, 1862) (Decapoda: Brachyura: Gecarcinucidae). European Journal of Taxonomy 798: 1-29. https://doi.org/10.5852/ejt.2022.798.1629

\section{Introduction}

Spiralothelphusa Bott, 1968, a freshwater crab genus of the family Gecarcinucidae Rathbun, 1904, was previously known from six species: S. fernandoi $\mathrm{Ng}$, 1994, and S. parvula (Fernando, 1961) from Sri 
Lanka; and S. gibberosa Pati \& Sudha Devi, 2015, S. hydrodroma (Herbst, 1794), S. senex (Fabricius, 1798), and S. wuellerstorfi (Heller, 1862) from India (Ng \& Tay 2001; Pati \& Sudha Devi 2015; Pati \& Thackeray 2018). In carapace morphology, Spiralothelphusa most resembles Oziotelphusa Müller, 1887 (see Ng \& Tay 2001), the only other genus with representatives from both India and Sri Lanka (Bahir et al. 2005). The longitudinally twisted male first gonopod of Spiralothelphusa separates it from Oziotelphusa, which possesses a male first gonopod with no obvious twisting in a longitudinal direction (Ng \& Tay 2001; Bahir \& Yeo 2005). Beenaerts et al. (2010) in a phylogenetic study noticed that Spiralothelphusa forms a monophyletic clade but nested within the paraphyletic clade of Oziotelphusa; both together are nevertheless monophyletic.

During a recent survey in Andhra Pradesh State of South India, some specimens of a hitherto unknown species of Spiralothelphusa were collected. The structure of the male first gonopod of this unknown species is so unique among the known species of the genus that we herein describe it as a new species. The new species, $S$. andhra sp. nov., has morphological affinities with $S$. wuellerstorfi. Phylogenetic analyses using mitochondrial cytochrome c oxidase subunit I (mt COI DNA) sequences are carried out to know the phylogenetic relationship between them and among the species of the monophyletic Spiralothelphusa.

The origin of $S$. wuellerstorfi is unknown because Heller (1862) mentioned four geographically disjunct regions (Ceylon, Nicobaren, Madras, and Taiti) to be associated with the species. The specimens from Madras, however, could not be traced recently in the Naturhistorisches Museum Wien, Vienna, Austria (NHMW), where most of the syntypes are located. It is very unlikely for an Indian or Sri Lankan species of freshwater crab to be also found in Nicobar or Tahiti ( $\mathrm{Ng} \&$ Tay 2001). Although Spiralothelphusa occurs in India and Sri Lanka, reliable records indicate that none of its species is common to both countries (cf. Ng \& Tay 2001; Bahir et al. 2005). All the known localities of S. wuellerstorfi are investigated in the present study. The identity of $S$. wuellerstorf is still uncertain because the former lectotype designation by Bott (1968) was not clear. Bott (1968) designated a male lectotype from NHMW without mention of its catalogue number or size. He had never illustrated the lectotype male designated by him. Without accurate information, the lectotype specimen designated by Bott (1968) became difficult to locate among several paralectotypes of the depository (Peter Dworschak, personal communication). A new lectotype is, therefore, designated herein for nomenclatural stability of $S$. wuellerstorfi. In the present study, $S$. wuellerstorf is redescribed, and the available specimens or the illustrated specimens from the known localities of the species are compared with the presently designated lectotype.

Spiralothelphusa is now represented by seven species, five from India. An illustrated identification key is provided for the species of Spiralothelphusa.

\section{Material and methods}

\section{Morphological analysis}

The taxonomic characters used for crab identification in the present study mostly follow $\mathrm{Ng} \&$ Tay (2001), with minor modification as per Davie et al. (2015). The terminologies for male first gonopod (or pleopod) used here, however, differ from those suggested by $\mathrm{Ng} \&$ Tay (2001) because of its longitudinal twisting in different degrees. A schematic diagram is provided for the terminologies and measurements of male first gonopod (Fig. 1). The terminologies for male second gonopod (or pleopod) are essentially after $\mathrm{Ng} \&$ Tay (2001). The terminologies and measurement of female sternum/vulvae are after Guinot et al. (2013) and Pati (2021), respectively. The width of the carapace was measured across the widest part of the carapace. The length of the carapace was measured medially from the edge of the frontal margin to the base of the posterior margin of the carapace excluding the dorsally visible pleonal somites. The height of the carapace was measured between mid-dorsal and mid-ventral surfaces 
beyond the level of branchiostegals up to the bottom of the thoracic sternum, which is consistent in all previous publications by the first author (S.K. Pati) and throughout the present work. The frontal width was measured in a straight line between the anterolateral edges of the front representing the frontal margin. All measurements are in $\mathrm{mm}$ and have been taken using a slide caliper or calibrated micrometer.

The line drawings were achieved from the digital tracings of the original illustrations or images using the GNU Image Manipulation Program (GIMP) software as suggested by Montesanto (2015). Setae and stippling effects were excluded in the line drawings of male telson and male first gonopod.

\section{Molecular analysis}

The previous phylogenetic study showed that the monophyletic Spiralothelphusa is nested within the paraphyletic Oziotelphusa, but both the genera formed a monophyletic clade (Beenaerts et al. 2010). Since the present study aims to determine the phylogenetic relationships among the species of the monophyletic Spiralothelphusa, we considered only those available sequences for the genus and selected two gecarcinucid species as outgroups: Barytelphusa cunicularis (Westwood in Sykes, 1836) and Sartoriana spinigera (Wood-Mason, 1871) (Table 1). Both representatives of the outgroup are from the Indian subcontinent and previously showed to form separate clades (Beenaerts et al. 2010), which are distant enough from the ingroup members to perform the phylogenetic analyses.

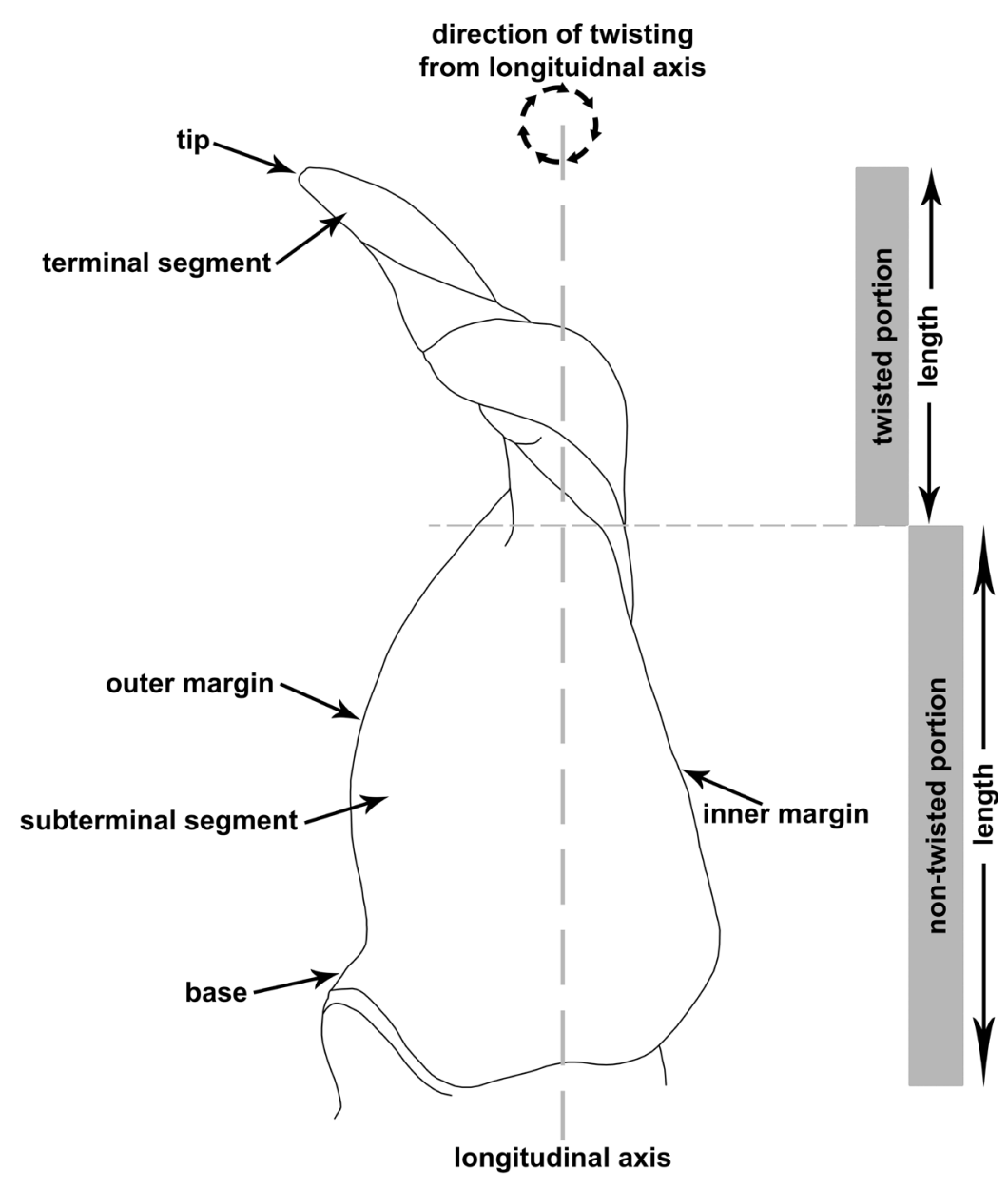

Fig. 1. Schematic diagram of a left male first gonopod (G1) showing terminologies and measurements. 


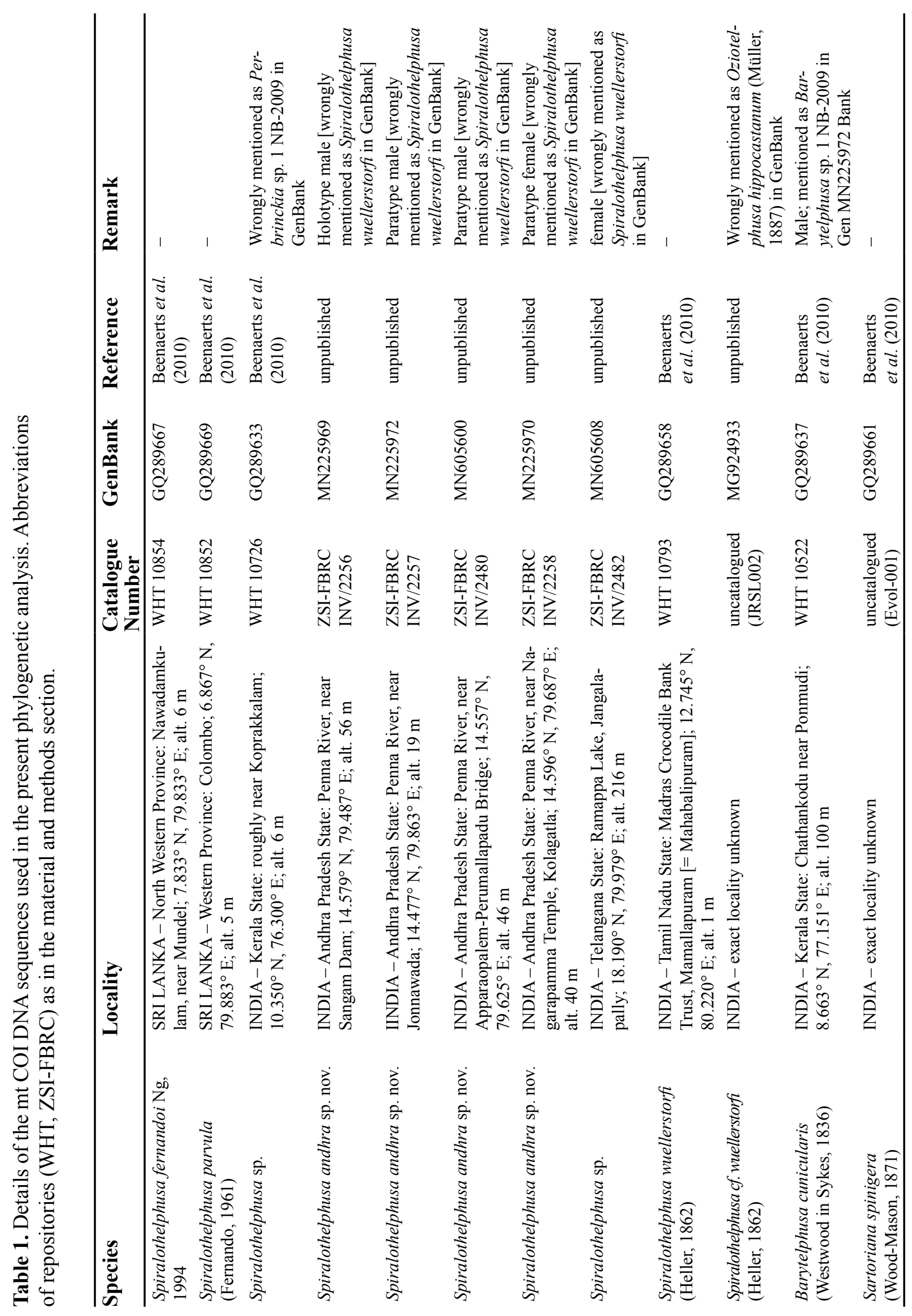


The related and homologous sequences ( $m$ t COI DNA) were acquired from the GenBank through BLAST and were initially aligned using MEGA version X (Kumar et al. 2018). The excess sequences were removed through visual inspection. The reliability of the final alignment was estimated by calculating the average p-distance (0.09) using the same software (Kumar et al. 2018). The best-fitting model of nucleotide substitution $(\mathrm{GTR}+\mathrm{G})$ was determined using Akaike Information Criterion $(\mathrm{AIC}=3881.26$; $-\operatorname{lnL}=1910.50$ ) in MEGA version X (Kumar et al. 2018). The maximum likelihood (ML) tree (Fig. 2) was constructed with 1000 thorough bootstrap replicates and GTR $+\mathrm{G}$ substitution model in raxmlGUI ver. 2.0 (Edler et al. 2021). The consensus-generated tree was viewed in FigTree ver. 1.4.4. The uncorrected pair-wise genetic distances (p-distances) between the species of Spiralothelphusa were also calculated (Table 2) in MEGA version X (Kumar et al. 2018).

\section{Abbreviations of repositories}

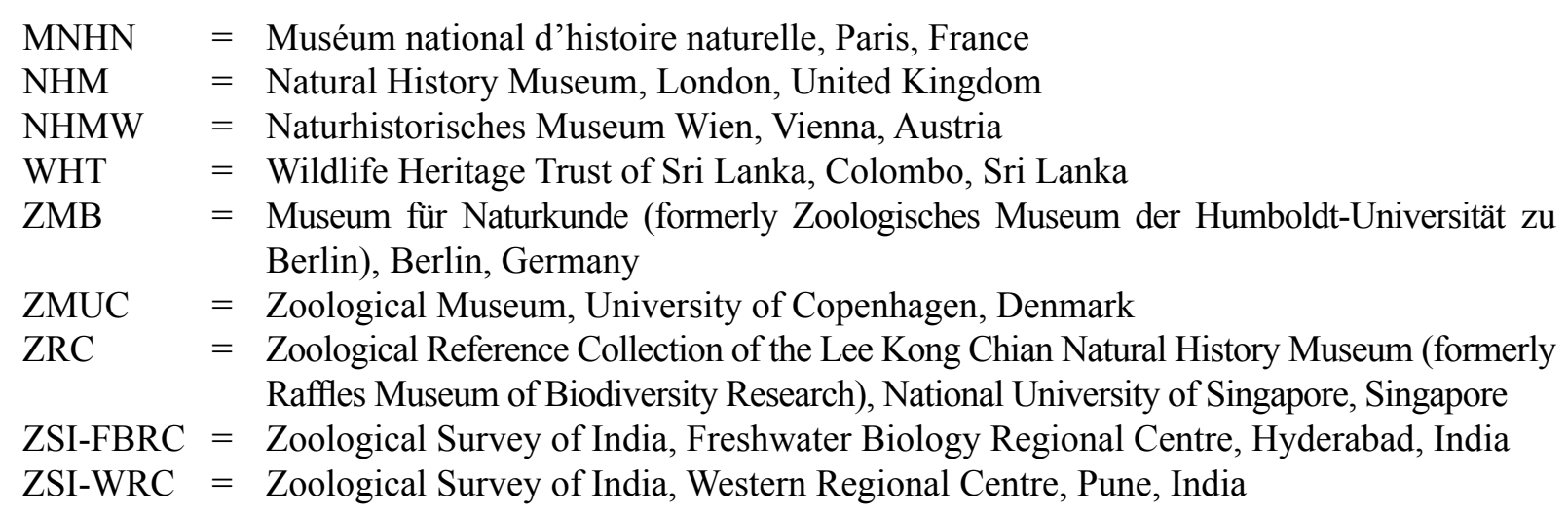

\section{Abbreviations}

$\begin{array}{ll}\mathrm{CH} & =\text { carapace height } \\ \mathrm{CL} & =\text { carapace length } \\ \mathrm{CW} & =\text { carapace width } \\ \mathrm{FW} & =\text { frontal width } \\ \mathrm{G} 1 & =\text { male first gonopod } \\ \mathrm{G} 2 & =\text { male second gonopod } \\ \mathrm{P} 2-\mathrm{P} 5 & =\text { pereiopods } 2 \text { to } 5 \text {, respectively } \\ \mathrm{S} 1-\mathrm{S} 8 & =\text { thoracic sternites } 1 \text { to } 8, \text { respectively } \\ \mathrm{S} 2 / \mathrm{S} 3 & =\text { suture between thoracic sternites } 2 \text { and } 3 \\ \mathrm{~S} 3 / \mathrm{S} 4 & =\text { suture between thoracic sternites } 3 \text { and } 4 \\ \mathrm{~S} 4 / \mathrm{S} 5 & =\text { suture between thoracic sternites } 4 \text { and } 5 \\ \mathrm{~S} 5 / \mathrm{S} 6 & =\text { suture between thoracic sternites } 5 \text { and } 6 \\ \mathrm{~S} 6 / \mathrm{S} 7 & =\text { suture between thoracic sternites } 6 \text { and } 7 \\ \mathrm{~S} 7 / \mathrm{S} 8 & =\text { suture between thoracic sternites } 7 \text { and } 8 \\ \mathrm{SW} & =\text { maximum width of sternum } \\ \mathrm{VD} & =\text { closest distance between female vulvae }\end{array}$


Table 2. Uncorrected pair-wise genetic distances (p-distances) between the species of Spiralothelphusa having mt COI DNA sequences. 1. Spiralothelphusa andhra sp. nov. (MN225969). 2. Spiralothelphusa andhra sp. nov. (MN225972). 3. Spiralothelphusa andhra sp. nov. (MN605600). 4. Spiralothelphusa andhra sp. nov. (MN225970). 5. Spiralothelphusa sp. (MN605608). 6. Spiralothelphusa sp. (GQ289633). 7. Spiralothelphusa fernandoi Ng, 1994 (GQ289667). 8. Spiralothelphusa wuellerstorfi (Heller, 1862) (GQ289658). 9. Spiralothelphusa cf. wuellerstorfi (Heller, 1862) (MG924933). 10. Spiralothelphusa parvula (Fernando, 1961) (GQ289669).

\begin{tabular}{lllllllllll}
\hline & $\mathbf{1}$ & $\mathbf{2}$ & $\mathbf{3}$ & $\mathbf{4}$ & $\mathbf{5}$ & $\mathbf{6}$ & $\mathbf{7}$ & $\mathbf{8}$ & $\mathbf{9}$ & $\mathbf{1 0}$ \\
\hline $\mathbf{1}$ & 0.000 & & & & & & & & & \\
$\mathbf{2}$ & 0.002 & 0.000 & & & & & & & & \\
$\mathbf{3}$ & 0.003 & 0.002 & 0.000 & & & & & & & \\
$\mathbf{4}$ & 0.002 & 0.000 & 0.002 & 0.000 & & & & & & \\
$\mathbf{5}$ & 0.037 & 0.036 & 0.037 & 0.036 & 0.000 & & & & & \\
$\mathbf{6}$ & 0.074 & 0.073 & 0.073 & 0.073 & 0.068 & 0.000 & & & & \\
$\mathbf{7}$ & 0.074 & 0.073 & 0.071 & 0.073 & 0.071 & 0.034 & 0.000 & & & \\
$\mathbf{8}$ & 0.076 & 0.074 & 0.073 & 0.074 & 0.076 & 0.061 & 0.059 & 0.000 & & \\
$\mathbf{9}$ & 0.068 & 0.066 & 0.064 & 0.066 & 0.074 & 0.058 & 0.056 & 0.020 & 0.000 & \\
$\mathbf{1 0}$ & 0.090 & 0.088 & 0.088 & 0.088 & 0.090 & 0.078 & 0.076 & 0.069 & 0.068 & 0.000 \\
\hline
\end{tabular}

\section{Results}

\section{Taxonomy}

Phylum Arthropoda von Siebold, 1848

Subphylum Crustacea Brünnich, 1772

Class Malacostraca Latreille, 1802

Order Decapoda Latreille, 1802

Infraorder Brachyura Latreille, 1802

Superfamily Gecarcinucoidea Rathbun, 1904

Family Gecarcinucidae Rathbun, 1904

Genus Spiralothelphusa Bott, 1968

\section{Type species}

Cancer hydrodroma Herbst, 1794, by original designation; gender feminine.

Spiralothelphusa wuellerstorfi (Heller, 1862)

Figs 3-6, 7B, K, M

Thelphusa wüllerstorfi Heller, 1862: 520.

Paratelphusa innominata Fernando, 1960: 210, figs 6f, 12b, 13c, d, 14, 15 (part). 
Thelphusa leschenaudii - Heller 1865: 32 (not Thelpheusa leschenaudii H. Milne Edwards, 1837).

Telphusa leschenaultii - Wood-Mason 1871: 202 (part) (not Thelpheusa leschenaudii H. Milne Edwards, 1837).

Telphusa leschenaulti - Henderson 1893: 382 (part). - Ortmann 1893: 489. - Bürger 1894: 2 (not Thelpheusa leschenaudii $\mathrm{H}$. Milne Edwards, 1837).

Potamon aurantium - Ortmann 1897: 302 (part) (not Cancer aurantius Herbst, 1799).

Potamon wüllerstorfi - De Man 1898: 438 (list).

Potamon (Potamon) hydrodromus - Rathbun 1904: 287, not pl. 12 fig. 3 (part) (not Cancer hydrodroma Herbst, 1794).

Spiralothelphusa wuellerstorf - Bott 1968: 404, figs 3-4, 26; 1970: 97, pl. 18 figs 12-14, pl. 29 fig. 68. — Ng \& Tay 2001: 190, figs 23a-k, 24a-b, h-1, 25a, b (part). — Beenaerts et al. 2010: 188, 190, tables S1, S4 (listed only in phylogenetic tree and supplementary files). — Pati \& Sudha Devi 2015: 416 (part).

\section{Diagnosis}

Carapace broader than long $(\mathrm{CW} / \mathrm{CL}=1.3)$, deep $(\mathrm{CH} / \mathrm{CL}=0.7-0.8)$; dorsal surface strongly convex in frontal view; epigastric cristae well-developed, sharp, distinctly anterior to postorbital cristae; postorbital cristae sharp, distinctly curved; external orbital angle triangular; epibranchial tooth distinct, blunt to slightly sharp, above level of postorbital cristae; branchial regions gently inflated; cervical grooves shallow, narrow, discontinuous, not reaching to level of postorbital cristae; suborbital margin concave, discontinuous with supraorbital margin; frontal median triangle complete, as broad as frontal margin, lateral margins joining dorsal margin; frontal margin medially concave in dorsal view; epistomal medial lobe with distinct, blunt tooth (Figs 3A-B, 5A-B). Eyes relatively small as compared to orbital space (Figs 3B, 5B). Third maxilliped exopod with well-developed flagellum. Chelipeds smooth, subequal or unequal; chela with elongated dactylus and palm; carpus with long, narrow, sharp inner distal major tooth and very low sub-basal granule; merus lacking subterminal spine (Figs 3A-C, 5A-C). Ambulatory legs moderately stout, shorter than chelipeds (Figs 3A, C, 5A, C). Male S1 and S2 separated by deep groove; male S2/S3 visible as shallow medial depression, not reaching lateral margins; male S3/S4 only visible as shallow lateral depressions (Figs 3C, 4A). Male sternopleonal cavity reaching to imaginary

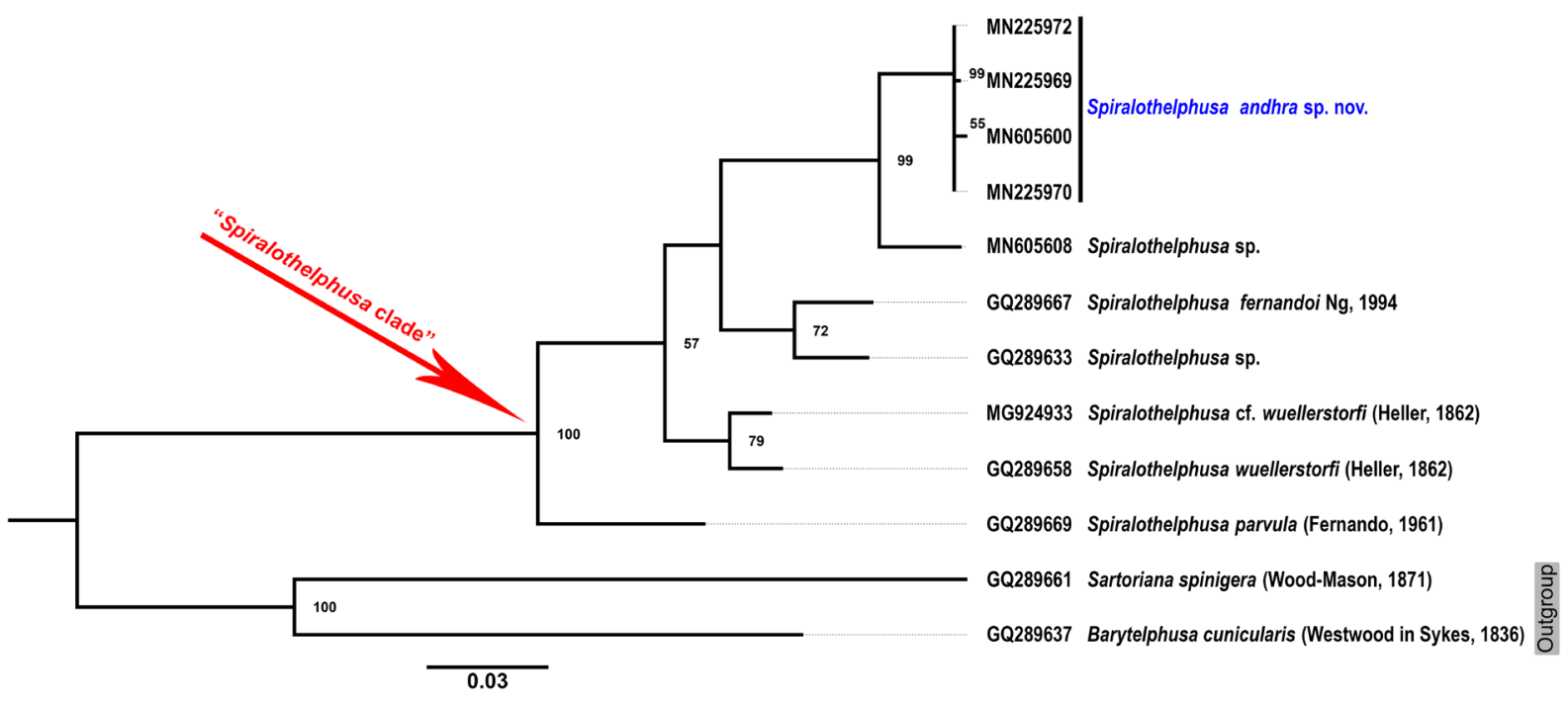

Fig. 2. Maximum Likelihood (ML) phylogram for Spiralothelphusa Bott, 1968 based on $603 \mathrm{bp}$ of $\mathrm{mt}$ COI DNA. The bootstrap value of ML analysis is shown at each node, except for values $<50 \%$. 


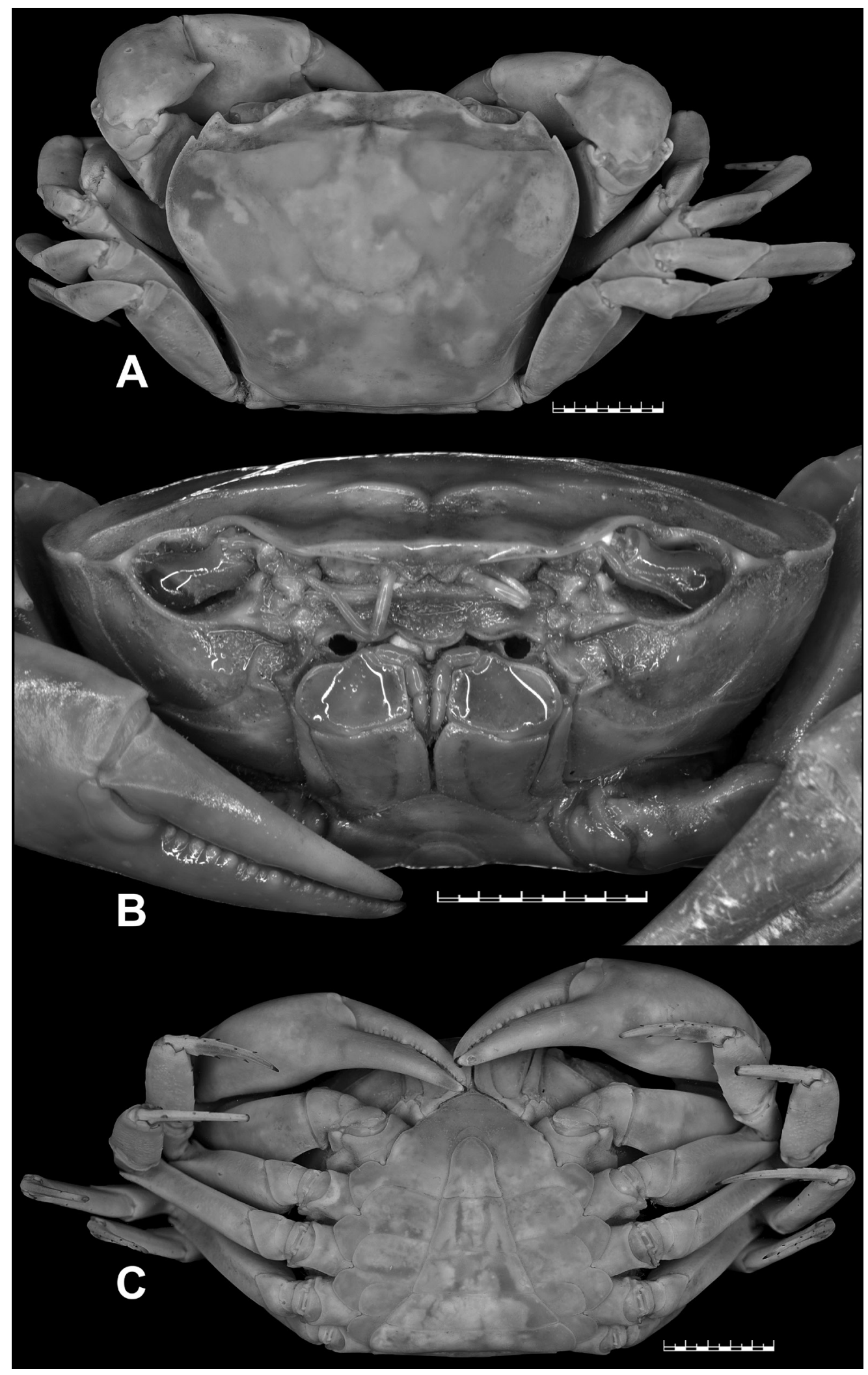

Fig. 3. Spiralothelphusa wuellerstorfi (Heller, 1862), lectotype, ô $(37.4 \times 28.5 \mathrm{~mm})$ (NHMW CR 27063). A. Entire animal, dorsal view. B. Cephalothorax, frontal view. C. Entire animal, ventral view. Scale bar $=10 \mathrm{~mm}$. 
line joining anterior part of cheliped coxae (Figs 3C, 4A). Male pleon narrowly triangular, with concave lateral margins; somite 6 trapezoidal, relatively broader (proximal width circa 1.6 times medial length), with gently concave lateral margins (Figs $3 \mathrm{C}, 7 \mathrm{M}$ ). Male telson slightly longer than pleonal somite 6, with concave lateral margins and narrow apex (Figs 3C, 7M). G1 relatively slender, with tip gently hooked downwards; terminal segment and distal portion of subterminal segment longitudinally strongly twisted full turn, clockwise in left G1 and anticlockwise in right G1; twisted portion long, circa 0.5 times length of non-twisted portion; non-twisted portion with outer margin sharply, relatively less strongly curved, straight towards base (Figs 4B-C, 6A-C, 7K). G2 circa 1.0-1.1 times length of G1; distal segment long, circa 0.5 times length of basal segment (Fig. 4D). Female pleonal somites and telson in adult broadly ovate (Fig. 5C). Vulvae in adult on S6 positioned apart from each other (VD/SW=circa 0.3 ), each ventrally opened, subovate, large (occupying circa 0.6 times length of S6), positioned close to S5/S6 (Fig. 5D).

\section{Material examined}

Lectotype (designated herein)

INDIA 1 O , adult(CW 37.4 mm, CL $28.5 \mathrm{~mm}$, CH $19.6 \mathrm{~mm}$, FW $12.7 \mathrm{~mm})$; "Nicobaren" [sic]; 1857-1859; Novara exped.; NHMW CR 27063 (formerly NHMW CR 24937, labelled as 'Thelphusa Leschenaudii M. Edw., Nicobaren, Frfld.').

\section{Paralectotypes}

INDIA 1 웅, adult (CW $37.8 \mathrm{~mm}, \mathrm{CL} 28.6 \mathrm{~mm}, \mathrm{CH} 21.6 \mathrm{~mm}, \mathrm{FW} 12.4 \mathrm{~mm}$ ); same collection data as for lectotype; NHMW CR 27064 (formerly NHMW CR 24937, labelled as 'Thelphusa Leschenaudii M. Edw., Nicobaren, Frfld.' $) \cdot 4$ तै ${ }^{\lambda}(32.3 \times 24.5 \mathrm{~mm} ; 31.2 \times 24.4 \mathrm{~mm} ; 30.1 \times 23.5 \mathrm{~mm} ; 26.8 \times 21.3 \mathrm{~mm})$, 4 우오 $(23.9 \times 18.0 \mathrm{~mm} ; 23.8 \times 19.5 \mathrm{~mm} ; 23.7 \times 18.8 \mathrm{~mm} ; 23.6 \times 18.6 \mathrm{~mm})$; same collection data as

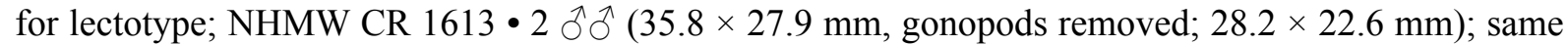
collection data as for lectotype; NHMW CR $24936 \bullet 3$ 우 $(37.8 \times 29.2 \mathrm{~mm} ; 34.5 \times 27.5 \mathrm{~mm} ; 32.3 \times$ $25.3 \mathrm{~mm})$; same collection data as for lectotype; NHMW CR $24937 \bullet 9$ subadults $(26.0 \times 20.2 \mathrm{~mm}$; $25.6 \times 18.9 \mathrm{~mm} ; 20.6 \times 16.1 \mathrm{~mm} ; 18.8 \times 14.6 \mathrm{~mm} ; 18.8 \times 14.4 \mathrm{~mm} ; 18.6 \times 13.9 \mathrm{~mm} ; 17.6 \times 13.2 \mathrm{~mm}$; $17.3 \times 12.8 \mathrm{~mm} ; 15.4 \times 11.6 \mathrm{~mm}$ ); same collection data as for lectotype; NHMW CR 24938 .

SRI LANKA • 1 ○े $(28.0 \times 23.0 \mathrm{~mm}$, gonopods removed $), 1$ + $(28.2 \times 21.5 \mathrm{~mm}), 3$ subadults $(15.1 \times$ $11.2 \mathrm{~mm} ; 13.8 \times 10.7 \mathrm{~mm} ; 12.3 \times 10.1 \mathrm{~mm})$; "Ceylon" [sic]; 1857-1859; Novara exped.; NHMW CR 24939.

FRENCH POLYNESIA • $2 \hat{\widehat{\partial}} \widehat{\partial}(36.3 \times 28.4 \mathrm{~mm} ; 33.0 \times 23.9 \mathrm{~mm})$; "Taiti" [sic]; 1857-1859; Novara exped.; NHMW CR $24940 \bullet 4$ えへ $(32.5 \times 25.1 \mathrm{~mm}$, right gonopods removed; $32.3 \times 24.4 \mathrm{~mm} ; 31.3 \times$ $23.5 \mathrm{~mm}$, right gonopods removed; $30.5 \times 23.6 \mathrm{~mm}), 3$ q $9(36.7 \times 28.3 \mathrm{~mm} ; 35.9 \times 28.2 \mathrm{~mm} ; 34.9 \times$

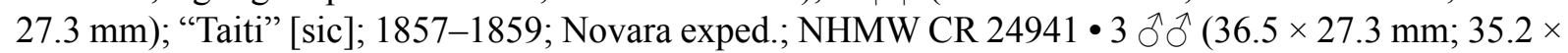
$27.3 \mathrm{~mm} ; 34.1 \times 26.0 \mathrm{~mm}), 2$ 우우 $(37.1 \times 29.0 \mathrm{~mm} ; 33.9 \times 27.1 \mathrm{~mm})$; “Taiti” [sic]; 1857-1859; Novara exped.; NHMW CR 24942.

\section{Additional material}

INDIA - Tamil Nadu State - $3 \hat{\jmath} \hat{o}, 1$ क; Chennai District, Puzhal Lake, near Pammathukulam; $13.159^{\circ}$ N, $80.159^{\circ}$ E; alt. $15 \mathrm{~m} ; 19$ Sep. 2020; H. Sruthi leg.; ZSI-

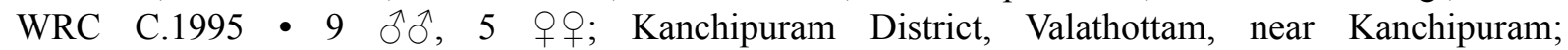
$12.784^{\circ} \mathrm{N}, 79.704^{\circ} \mathrm{E}$; alt. $79 \mathrm{~m}$; 16 Nov. 2019; P. Kalaimagal et al. leg.; ZSI-WRC C.1960 - $1 \mathrm{~d}$; Kanchipuram District, paddy fields in front of Madras Crocodile Bank, Mamallapuram [=Mahabalipuram]; $12.745^{\circ}$ N, 80.220 E ; alt. 1 m; 7 Dec. 1997; M.M. Bahir leg.; ZRC 2003.0243 (formerly WHT 10749). 


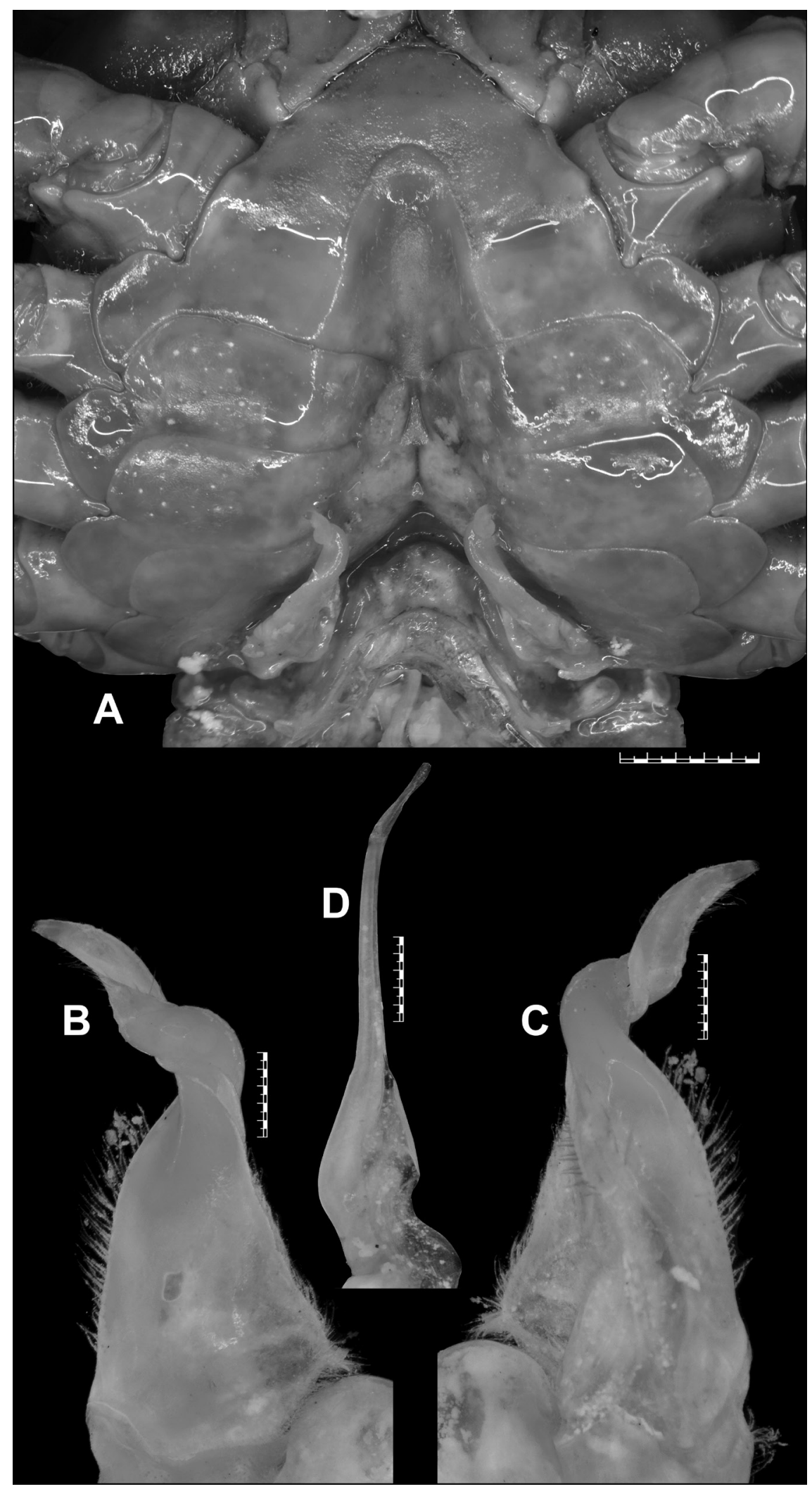

Fig. 4. Spiralothelphusa wuellerstorfi (Heller, 1862), lectotype, ô $(37.4 \times 28.5 \mathrm{~mm})$ (NHMW CR 27063). A. Thoracic sternites with G1 in situ. B. Left G1, dorsal view. C. Left G1, ventral view. D. Left G2. Scale bars: $A=5 \mathrm{~mm}$; $B-D=1 \mathrm{~mm}$. 


\section{Description of male lectotype}

Carpace broader than long $(\mathrm{CW} / \mathrm{CL}=1.3)$, deep $(\mathrm{CH} / \mathrm{CL}=0.7)$; dorsal surface strongly convex in frontal view, smooth except for epigastric cristae, postorbital cristae and posterolateral surfaces; anterolateral margins gently convex, cristate, shorter than posterolateral margins; posterolateral margins medially concave; epigastric cristae well-developed, sharp, distinctly anterior to postorbital cristae; postorbital cristae sharp, distinctly curved, each sloping posteriorly towards postorbital region, then anteriorly towards anterolateral margin; external orbital angle triangular, with outer margin circa 2 times length of inner margin; epibranchial tooth distinct, blunt, above level of postorbital cristae; postorbital region concave; branchial regions gently inflated; cervical grooves shallow, narrow, discontinuous, not reaching to level of postorbital cristae; mesogastric groove deep, narrow, short, bifurcated posteriorly; H-shaped groove distinct; subhepatic region rugose; suborbital region almost smooth; pterygostomial region smooth; supraorbital margin cristate, smooth, medially straight; suborbital margin concave, cristate with low granules, discontinuous with supraorbital margin; frontal median triangle complete, as broad as frontal margin, lateral margins joining dorsal margin; front gently sloping downwards, subtrapezoidal; frontal margin smooth, cristate, broad $(\mathrm{FW} / \mathrm{CW}=0.3)$, medially concave in dorsal view; epistomal medial lobe with distinct, blunt tooth (Fig. 3A-B).

Eyes relatively small as compared to orbital space; eyestalk short, narrow, laterally concave; cornea moderately large, pigmented (Fig. 3B).

Antennules long, folded in longitudinally broad fossae; antennae very long, reaching beyond eyestalk (Fig. 3B). Mandibular palp 2-segmented; terminal segment bilobed. First, second maxillipeds each with long flagellum on exopod. Third maxillipeds cover most of buccal cavity when closed; ischium subrectangular, longer than broad, with deep, oblique submedial groove; merus subrectangular, broader than long, sunken; exopod moderately stout, distally narrow, longer than ischium, reaching proximal half of merus, with well-developed flagellum (Fig. 3B).

Chelipeds smooth, unequal, left chela larger. Major chela with blunt teeth on each finger, very small gape when fingers closed; dactylus curved, slender, elongated; palm smooth, elongated; carpus generally smooth, gently inflated, with long, narrow, blunt (eroded) inner distal major tooth and very low subbasal granule; merus generally smooth, lacking subterminal spine (Fig. 3A-C).

Ambulatory legs moderately stout, shorter than chelipeds, P3 longest, glabrous; merus (P2-P5) lacking subdistal spine; dactylus (P2-P5) gently recurved, subequal in length to propodus, with few distinct, sharp chitinous spines on margins (Fig. 3A, C).

Thoracic sternites smooth, glabrous, sparsely punctate; S1 and S2 separated by deep groove; S2/S3 visible as shallow medial depression, not reaching lateral margins; S3/S4 only visible as shallow lateral depressions; S4/S5, S5/S6, S6/S7 deep, narrow, medially interrupted; S7/S8 shallow, narrow, with medial transverse ridge, interrupting longitudinal groove (Figs 3C, 4A). Pleonal locking mechanism with prominent tubercle on submedial part of S5 (Fig. 4A). Sternopleonal cavity deep, long, reaching to imaginary line joining anterior part of cheliped coxae (Figs 3C, 4A).

Pleon narrowly triangular, with concave lateral margins; somites 1, 2 narrower than somite 3; somite 3 broadest, with strongly convex lateral margins; somites 4, 5 trapezoidal, with straight lateral margins; somite 6 trapezoidal, broader than long (proximal width circa 1.6 times medial length), distinctly longer than preceding somites, with gently concave lateral margins (Figs 3C, 7M). Telson slightly longer than pleonal somite 6 , slightly longer than broad (medial length circa 1.1 times proximal width), with concave lateral margins and narrow apex (Figs 3C, 7M). 

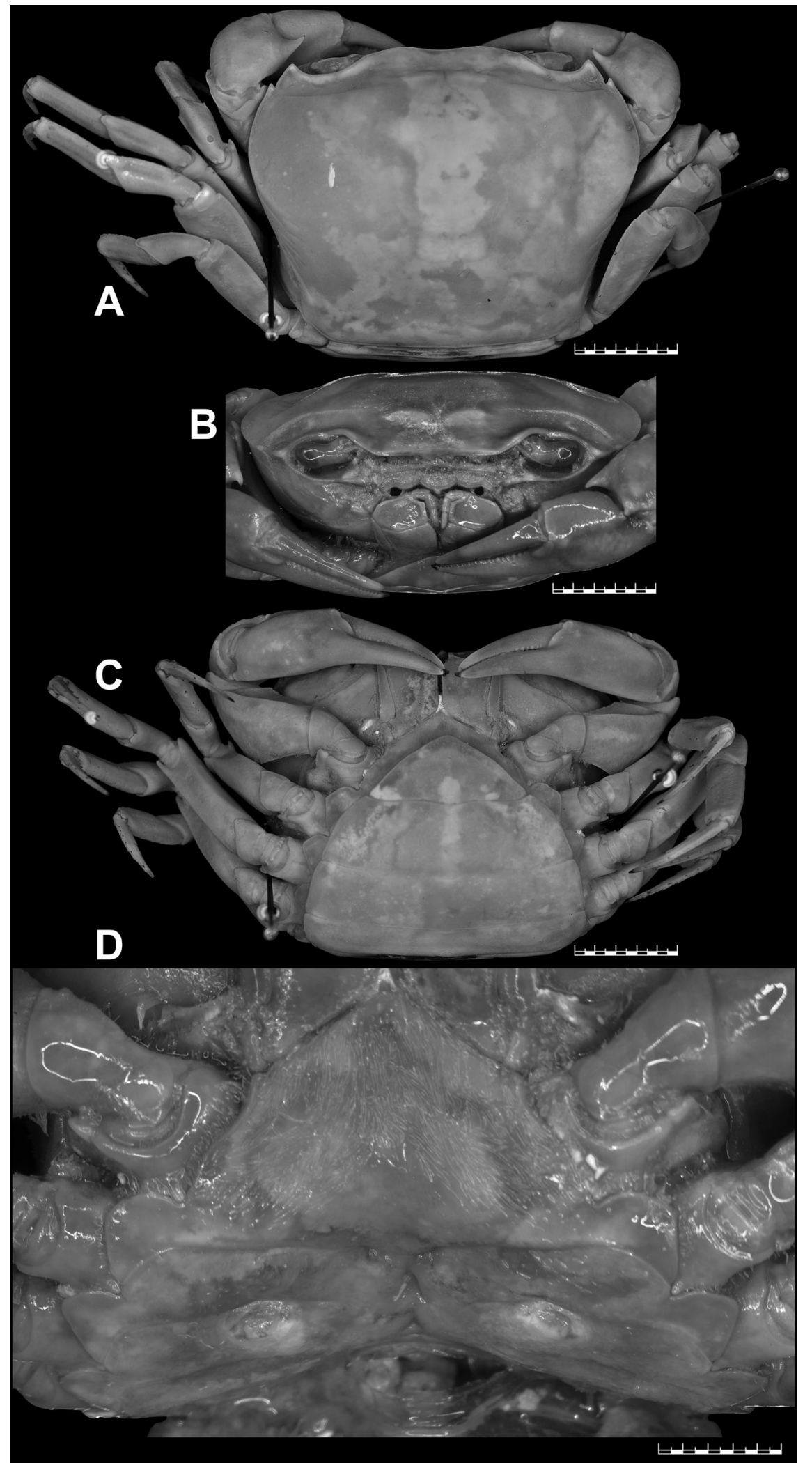

Fig. 5. Spiralothelphusa wuellerstorfi (Heller, 1862), paralectotype, $q(37.8 \times 28.6 \mathrm{~mm})$ (NHMW CR 27064). A. Entire animal, dorsal view. B. Cephalothorax, frontal view. C. Entire animal, ventral view. D. Thoracic sternites showing vulvae. Scale bars: $A-C=10 \mathrm{~mm}$; $=5 \mathrm{~mm}$. 
G1 relatively slender, with tip gently hooked downwards, not reaching S5/S6; terminal segment and distal portion of subterminal segment longitudinally strongly twisted full turn, clockwise in left G1 and anticlockwise in right G1; twisted portion long, circa 0.5 times length of non-twisted portion; non-twisted portion with outer margin sharply curved, straight towards base; groove for G2 lateral (Figs 4A-C, 7K). G2 circa 1.1 times length of G1; distal segment long, circa 0.5 times length of basal segment (Fig. 4D).

\section{Remarks}

Bott (1968) listed the lectotype (male) and seven paralectotypes (four males and three females) for S. wuellerstorfi from NHMW, with locality as "Taiti", most probably the Nicobar Islands. Neither the specific catalogue number nor the size of the lectotype was mentioned by Bott (1968). Bott also never illustrated the lectotype the lectotype male designated by him. Instead, he provided the figures of a male specimen from "Nikobaren" located in the Forschungsinstitut Senckenberg, Frankfurt am Main, Germany (SMF 4406) (see Bott 1968: figs 3-4, 26; 1970: pl. 18 figs 12-14, pl. 29 fig. 68). NHMW possesses three lots (NHMW CR 24940-24942) from "Taiti”, and the lectotype is supposedly designated from the lot NHMW CR 24941 that actually contains four males and three females. Peter Dworschak, the former curator of the Crustacea collections of NHMW, confirmed that the lectotype designated by Bott (1968) was not marked specifically among the paralectotypes, and the right gonopods have been removed from two males but kept in the same vial. Without accurate information on catalogue number and size of the specimen, and in the absence of any illustration, the particular lectotype is now difficult to trace among several paralectotypes of the depository, even from the most likely lot NHMW CR 24941 (Peter Dworschak, personal communication). Bott (1968), therefore, did not unambiguously select a particular syntype to act as the unique name-bearing type of $S$. wuellerstorfi as required by Article 74.5 of the International Code of the Zoological Nomenclature (ICZN 1999). A new lectotype should be now designated to avoid further confusion and to stabilize the taxonomy of the species. NHMW possesses 43 syntypes (17 males, 14 females, and 12 juveniles). Among these syntypes, the largest male is from the lot NHMW CR 24937 that contains this lone male and four females. This largest and intact adult male $(37.4 \times 28.5 \mathrm{~mm})$ (NHMW CR 24937) from "Nicobaren" is hereby designated as the lectotype, with a new catalogue number (NHMW CR 27063), for the nomenclatural stability of S. wuellerstorfi. The presently designated lectotype is described and illustrated (Figs $3 \mathrm{~A}-\mathrm{C}, 4 \mathrm{~A}-\mathrm{D}, 7 \mathrm{~K}, \mathrm{M}$ ). One of the female paralectotypes from the lot NHMW CR 24937 (now with a new catalogue number, NHMW CR 27064) is also illustrated here (Fig. 5A-D).

The female paralectotype (NHMW CR 27064) of S. wuellerstorfi examined in this study is an adult and possesses most of the non-sexual character states (Fig. 5A-C) as those in the male lectotype designated herein. Its epibranchial tooth, however, is relatively sharper (Fig. 5A) than that of the male lectotype (Fig. 3A). The female paralectotype (NHMW CR 27064) has almost equal-sized chelipeds, each with a sharp inner distal major tooth on the carpus (Fig. 5A-C), whereas the male lectotype possesses unequal chelipeds, each with an eroded inner distal major tooth on the carpus that appears blunt (Fig. 3A-C). The pleonal somites and telson of the female paralectotype (NHMW CR 27064) are broadly ovate, which cover the thoracic sternum except for the lateral edges when closed. The pleonal somite 1 is the shortest; pleonal somites 2-5 are progressively longer; pleonal somite 6 is the longest, much broader than long, slightly longer than the telson, with the convex lateral margins (Fig. 5C). The telson is triangular, much broader than long, with almost straight lateral margins (Fig. 5C). The vulvae on S6 of the female paralectotype (NHMW CR 27064) are positioned apart from each other (VD/SW = circa 0.3), each opens ventrally, subovate, large (occupying circa 0.6 times the length of S6), positioned close to S5/S6, and surrounded by a raised, broad rim (Fig. 5D).

The paratype male (MNHN BP 183) of S. wuellerstorfi from Nicobar illustrated in Ng \& Tay (2001: fig. 24h-1), which should now be regarded as the paralectotype, is identical with the lectotype male (NHMW CR 27063) in the G1 structure. The male specimen from Sri Lanka (MNHN BP 11437; formerly 
labelled as 'Spiralothelphusa hydrodroma'; probably determined by Rathbun) also has a similar G1 (see $\mathrm{Ng} \&$ Tay, 2001: 24a-b) as in the lectotype male (NHMW CR 27063) of S. wuellerstorfi (Figs 4B, 7K). $\mathrm{Ng} \&$ Tay (2001), however, doubted the locality data of this MNHN specimen from Sri Lanka.

Spiralothelphusa wuellerstorfi was originally collected during the Novara expedition between 18571859 from four distant localities, viz., Ceylon [= present-day Sri Lanka], Nicobaren [= present-day Nicobar Islands of India], Madras [= present-day Chennai of Tamil Nadu State], and Taiti [= Tahiti of French Polynesia] (Heller 1862). The locality labels from the Novara expedition were obviously wrong (Peter Dworschak, personal communication). All the species of Spiralothelphusa are restricted to mainland India and Sri Lanka (Ng \& Tay 2001; Pati \& Sudha Devi 2015). In fact, no primary freshwater crab belonging to Gecarcinucidae is so far known from the Nicobar Islands of India (cf. Pati \& Thackeray 2018). While documenting the brachyuran crabs of the Andaman and Nicobar Islands, Dev Roy \& Nandi (2012) commented that there was no report of $S$. wuellerstorf since Heller (1862, 1865). A recent expedition (during 2018) to the Nicobar Islands by the Zoological Survey of India also could not locate $S$. wuellerstorfi or any other gecarcinucid species (K.A. Subramanian, personal communication). The records of $S$. wuellerstorfi from Nicobar and Tahiti are thus incorrect. All the Sri Lankan species of freshwater crabs appear to be endemic (Bahir et al. 2005). Moreover, no species of Spiralothelphusa from Sri Lanka has a G1 like that of S. wuellerstorfi. Spiralothelphusa wuellerstorfi is, therefore, less likely to occur in Sri Lanka. It might be originated from "Madras", or possibly somewhere in the Tamil Nadu State, near the present-day Chennai. Scherzer (1861) while narrating the Novara expedition mentioned that the tanks (or artificial basins) in the Vellore region of Tamil Nadu supply irrigation water for rice fields, which could be the preferred habitat of $S$. wuellerstorfi. Unfortunately, no type material of $S$. wuellerstorfi from "Madras" could be located in NHMW (Peter Dworschak, personal communication). It seems none of the original localities of $S$. wuellerstorfi is correct.

Other known localities of $S$. wuellerstorfi are the Malabar Coast [= present-day the northern part of the Kerala State in the south-western coast of India] (H. Milne Edwards 1853; A. Milne-Edwards 1869; Wood-Mason 1871; Henderson 1893; Ortmann 1893, 1897; Rathbun 1904; Ng \& Tay 2001; Rajesh

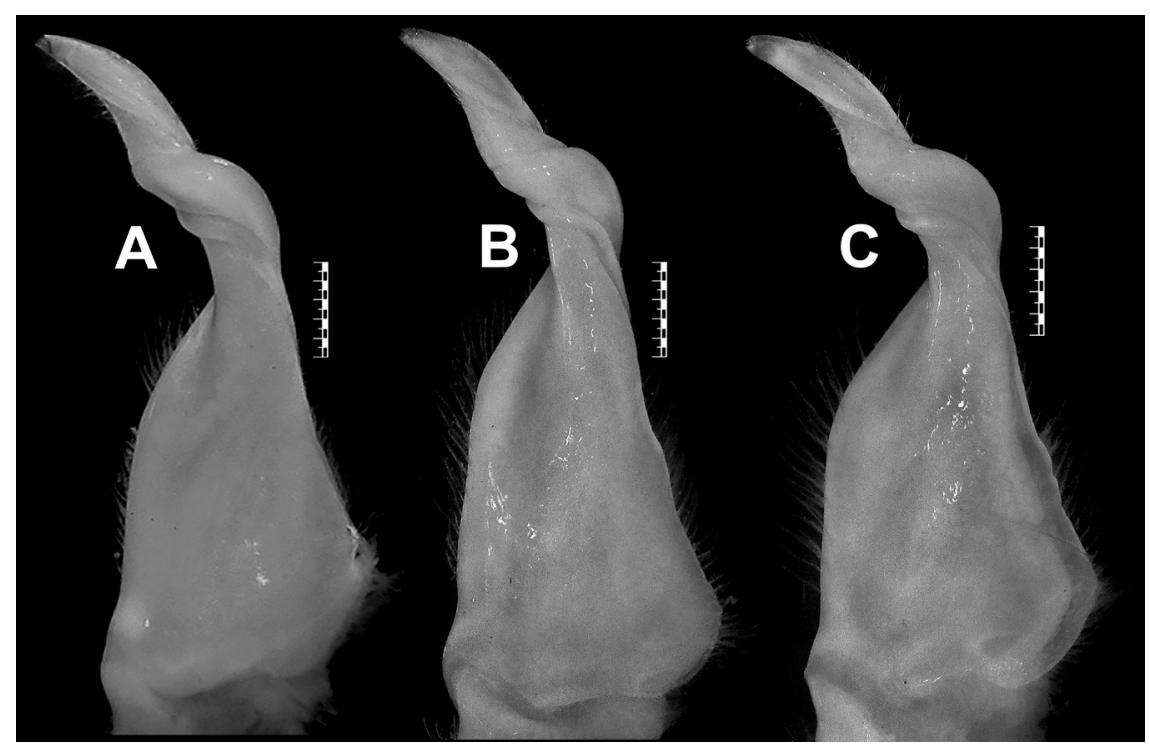

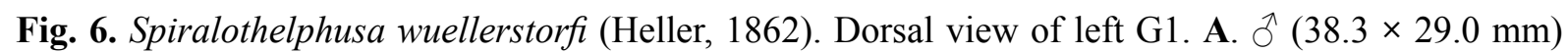
(ZRC 2003.0243; formerly WHT 10749). B. $\hat{\sigma}(41.0 \times 30.8 \mathrm{~mm})$ (ZSI-WRC C.1995). C. $\hat{\sigma}$ $(37.5 \times 27.1 \mathrm{~mm})($ ZSI-WRC C.1960). Scale bars $=1 \mathrm{~mm}$. 
et al. 2017), the Mulugu District of the Telangana State (Pati \& Mandal 2021), and the Tadoba National Park of the Maharashtra State (Pati \& Sharma 2014 sensu Pati \& Sudha Devi 2015). These localities are also incorrect since the G1s of the available specimens or illustrated specimens (see Pati \& Sharma 2014: fig. 11d-e; Ng \& Tay 2001: 24c-f are completely different from the lectotype (NHMW CR 27063) designated herein for $S$. wuellerstorfi. In fact, these specimens do not have a resemblance with the known species of Spiralothelphusa in the G1 structure. Beenaerts et al. (2010) included a specimen (WHT 10793) of S. wuellerstorfi from Mamallapuram [= Mahabalipuram] of the Kanchipuram District of Tamil Nadu in their phylogenetic analysis. The specimen of $S$. wuellerstorfi mentioned by Beenaerts et al. (2010) could not be traced in the most likely depository (ZRC). An adult male (ZRC 2003.0243; formerly WHT 10749) from the same locality (see additional material section), however, possesses an identical G1 (Fig. 6A) as that of the lectotype male (NHMW CR 27063) of S. wuellerstorfi (Figs 4B, $7 \mathrm{~K}$ ). Furthermore, the G1 of the holotype male (NHM 1892.7.15.241) of Paratelphusa innominata Fernando, 1960, from Madras illustrated in Ng \& Tay (2001: fig. 23i) is similar to that of the lectotype male (NHMW CR 27063) of S. wuellerstorfi (Figs 4B, 7K). Ng \& Tay (2001) argued that Paratelphusa innominata could be a junior synonym of $S$. wuellerstorfi, albeit some specimens of the former species from Sri Lanka reported by Fernando (1960) are now known as S. fernandoi (Ng 1994; Ng \& Tay 2001). Ng et al. (2008) also listed Paratelphusa innominata as one of the two primary synonyms of $S$. wuellerstorfi without any comment. We now confirm Paratelphusa innominata to be a junior subjective synonym of $S$. wuellerstorfi as their G1s have no difference. As such, the previous records of $S$. wuellerstorfi from Mamallapuram and "Madras" of Tamil Nadu are reliable. Some recently collected specimens of $S$. wuellerstorfi (see additional material section) from Chennai and Kanchipuram districts of Tamil Nadu further confirm the presence of $S$. wuellerstorf $i$ in the state as those specimens resemble the lectotype male (NHMW CR 27063) in the G1 structure (Figs 4B, 6B, C, 7K).

Heller (1865) provided emended characters for Thelphusa leschenaudii $\mathrm{H}$. Milne Edwards, 1837, followed by a brief description, which are almost identical to the Latin description of Thelphusa wüllerstorfi in Heller (1862). Heller (1865) also mentioned the same localities for Thelphusa leschenaudii as in Heller (1862) for Thelphusa wüllerstorfi. Although Heller (1865) did not provide any figure or illustration for Thelphusa leschenaudii, the description and localities indicate the species to be Spiralothelphusa wuellerstorfi. In any case, Thelphusa leschenaudii is a junior objective synonym of Telphusa indica Latreille, 1825, which itself is a junior synonym of Oziotelphusa aurantia (Herbst, 1799) (see Bahir \& Yeo 2005).

The species reported in Wood-Mason (1871), Henderson (1893), Ortmann (1893, 1897), Bürger (1894), De Man (1898), and Rathbun (1904) includes S. wuellerstorfi as presently defined as well as other taxa, viz., an unidentified species of Spiralothelphusa, Oziotelphusa aurantia, Oziotelphusa ceylonensis (Fernando, 1960), and Oziotelphusa ganjamensis (Pati \& Sharma, 2012), as evident from the locality records and/or published sources (Fernando 1960; Ng \& Tay 2001; Bahir \& Yeo 2005; Pati \& Vargila 2019).

In addition to Paratelphusa innominata, Thelphusa corrugata Heller, 1865, was included as a junior synonym of $S$. wuellerstorfi by $\mathrm{Ng}$ et al. (2008) without further explanation. Thelphusa corrugata was originally described from Madras and Java during the Novara expedition (Heller 1865). According to Cumberlidge (1997), Thelphusa corrugata is a junior synonym of Potamonautes perlatus (H. Milne Edwards, 1837) of the family Potamonautidae Bott, 1970. Since Potamonautes perlatus is an African species, the original localities of Thelphusa corrugata are certainly erroneous (Cumberlidge 1997). In a recent communication, Peter $\mathrm{Ng}$ informed that he has no clue how and why Thelphusa corrugata was assigned to S. wuellerstorfi in Ng et al. (2008), but that was an error, he now confirms based on the comments from Cumberlidge (1997). 

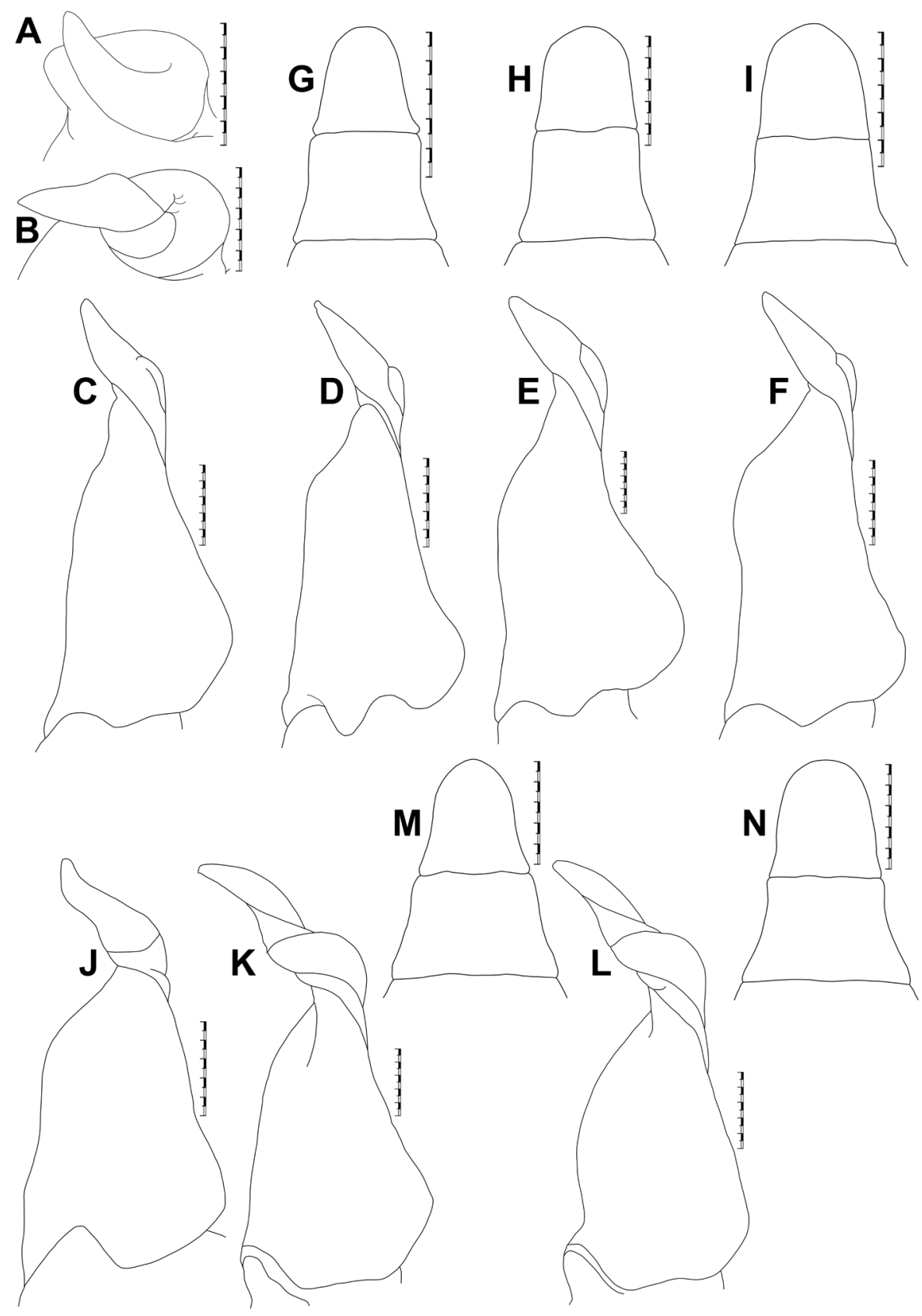

Fig. 7. Telson and G1 in Spiralothelphusa species showing diagnostic features. - A, F, I. Spiralothelphusa gibberosa Pati \& Sudha Devi, 2015, holotype, ô $(28.0 \times 23.0 \mathrm{~mm})$ (ZSI-WRC C.1186). - B, K, M. S. wuellerstorfi (Heller, 1862). B. đo $(37.5 \times 27.1 \mathrm{~mm})($ ZSI-WRC C.1960). K, M. Lectotype, ô $(37.4 \times 28.5 \mathrm{~mm})(\mathrm{NHMW}$ CR 27063). - C. S. hydrodroma (Herbst, 1794), topotype, ô $(27.2 \times 21.4 \mathrm{~mm})$ (ZMUC CRU 2824). - D, G. S. senex (Fabricius, 1798), lectotype, ठิ $(25.9 \times 20.3 \mathrm{~mm})($ ZMUC CRU 4626). - E, H. S. fernandoi Ng, 1994, holotype, đ̊ $(35.7 \times 26.5 \mathrm{~mm})$ (ZRC 1984.7547). - J. S. parvula (Fernando, 1961), paratype, ô $(19.4 \times 15.0 \mathrm{~mm})($ ZRC 1984.7887). - L, N. S. andhra sp. nov., holotype, ठิ $(37.8 \times 30.2 \mathrm{~mm})($ ZSI-FBRC INV/2256). A-B. Left G1, apical view. C, L. Right G1, dorsal view (horizontally flipped). D-F, J-K. Left G1, dorsal view. G-I, M-N. Pleonal somite 6 and telson. Scale bars: A-F, J-L $=1 \mathrm{~mm} ; \mathrm{G}-\mathrm{I}, \mathrm{M}-\mathrm{N}=5 \mathrm{~mm}$. C-E, G-H, J adapted from Ng \& Tay (2001) and I is adapted from Pati \& Sudha Devi (2015). 
Spiralothelphusa wuellerstorfi possesses a G1 with strongly, longitudinally twisted terminal segment and distal portion of the subterminal segment (fully turned clockwise in the left G1 and anticlockwise in the right G1) like that in $S$. parvula and $S$. andhra sp. nov. (Figs 4B-C, 6A-C, 7B, J-L, 10C-D, 11B, E; see Ng \& Tay 2001). Like $S$. andhra sp. nov., S. wuellerstorfi is nevertheless separated from $S$. parvula by the relatively slender G1, with the tip gently hooked downwards (Figs 4B-C, 6A-C, $7 \mathrm{~K}-\mathrm{L}, 10 \mathrm{C}-\mathrm{D}, 11 \mathrm{~B}, \mathrm{E}$ ) (vs relatively stouter G1, with the tip strongly curved upwards in S. parvula; Fig. 7J). On the other hand, $S$. wuellerstorfi can be distinguished from $S$. andhra sp. nov. in the shape of the male telson and G1 non-twisted portion (see Remarks for S. andhra sp. nov.). Spiralothelphusa wuellerstorfi need not be confused with the remaining Spiralothelphusa species as it possesses a G1 with fully turned terminal segment and distal portion of the subterminal segment (Fig. 7B) (vs G1 with half turned terminal segment and distal portion of the subterminal segment in S. fernandoi, S. gibberosa, S. hydrodroma, and S. senex; Fig. 7A; see Ng \& Tay 2001).

\section{Geographic distribution}

Spiralothelphusa wuellerstorfi is precisely known only from a few localities in the northeast of the Tamil Nadu State, South India (Fig. 8) (also see Remarks for the species).

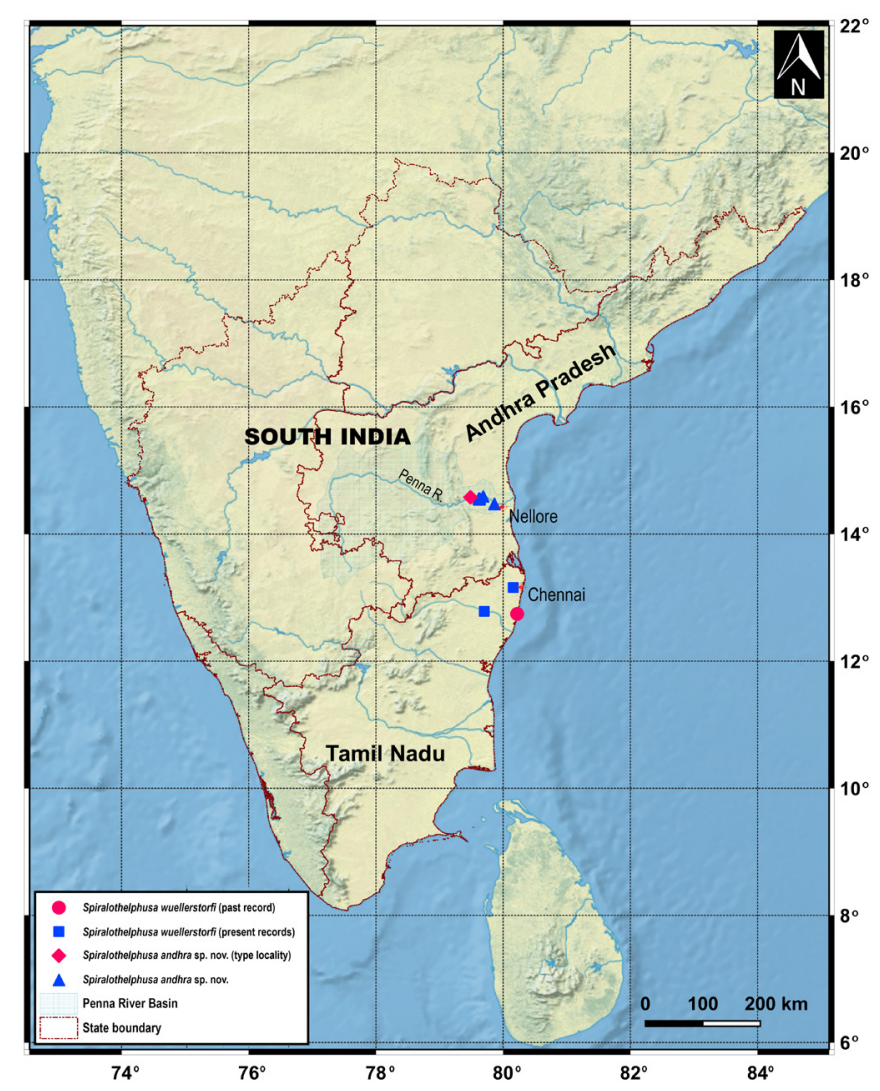

Fig. 8. Map of South India showing precise records of Spiralothelphusa wuellerstorfi (Heller, 1862) and collection sites of Spiralothelphusa andhra sp. nov. 


\section{Diagnosis}

Spiralothelphusa andhra sp. nov.

urn:1sid:zoobank.org:act:A02119B0-F118-48B2-BEF3-AC6A21B1D3E1

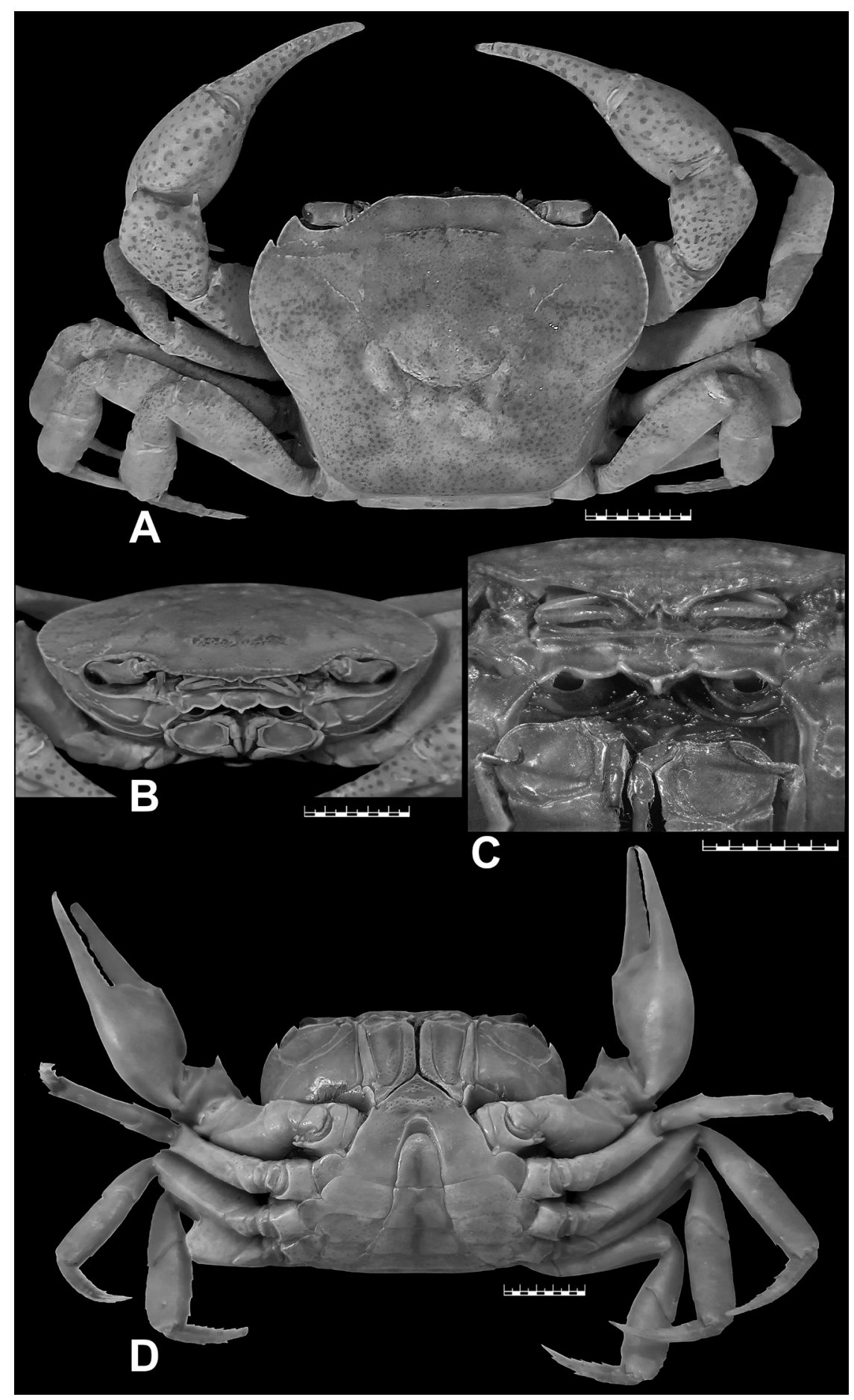

Fig. 9. Spiralothelphusa andhra sp. nov., holotype, $\widehat{\partial}(37.8 \times 30.2 \mathrm{~mm})($ ZSI-FBRC INV/2256). A. Entire animal, dorsal view. B. Cephalothorax, frontal view. C. Cephalothorax, frontal view of medial part. D. Entire animal, ventral view. Scale bars: A-B, D=10 mm; C=5 mm. 
Figs $7 \mathrm{~L}, \mathrm{~N}, 9-13$

Carapace broader than long $(\mathrm{CW} / \mathrm{CL}=1.3)$, deep $(\mathrm{CH} / \mathrm{CL}=0.6-0.7)$; dorsal surface strongly convex in frontal view; epigastric cristae well-developed, sharp, distinctly anterior to postorbital cristae; postorbital cristae sharp, almost straight to distinctly curved; external orbital angle triangular; epibranchial tooth distinct, sharp, above level of postorbital cristae; branchial regions gently inflated; cervical grooves shallow, narrow, discontinuous, not reaching to level of postorbital cristae; suborbital margin concave, discontinuous with supraorbital margin; frontal median triangle complete, as broad as frontal margin, lateral margins not joining dorsal margin; frontal margin medially gently concave in dorsal view; epistomal medial lobe with distinct, blunt tooth (Figs 9A-C, 11A, C, 12A, 13). Eyes relatively large as compared to orbital space (Fig. 9B). Third maxilliped exopod with well-developed flagellum (Fig. 9C). Chelipeds generally smooth, subequal or unequal; chela with elongated dactylus and palm; carpus with

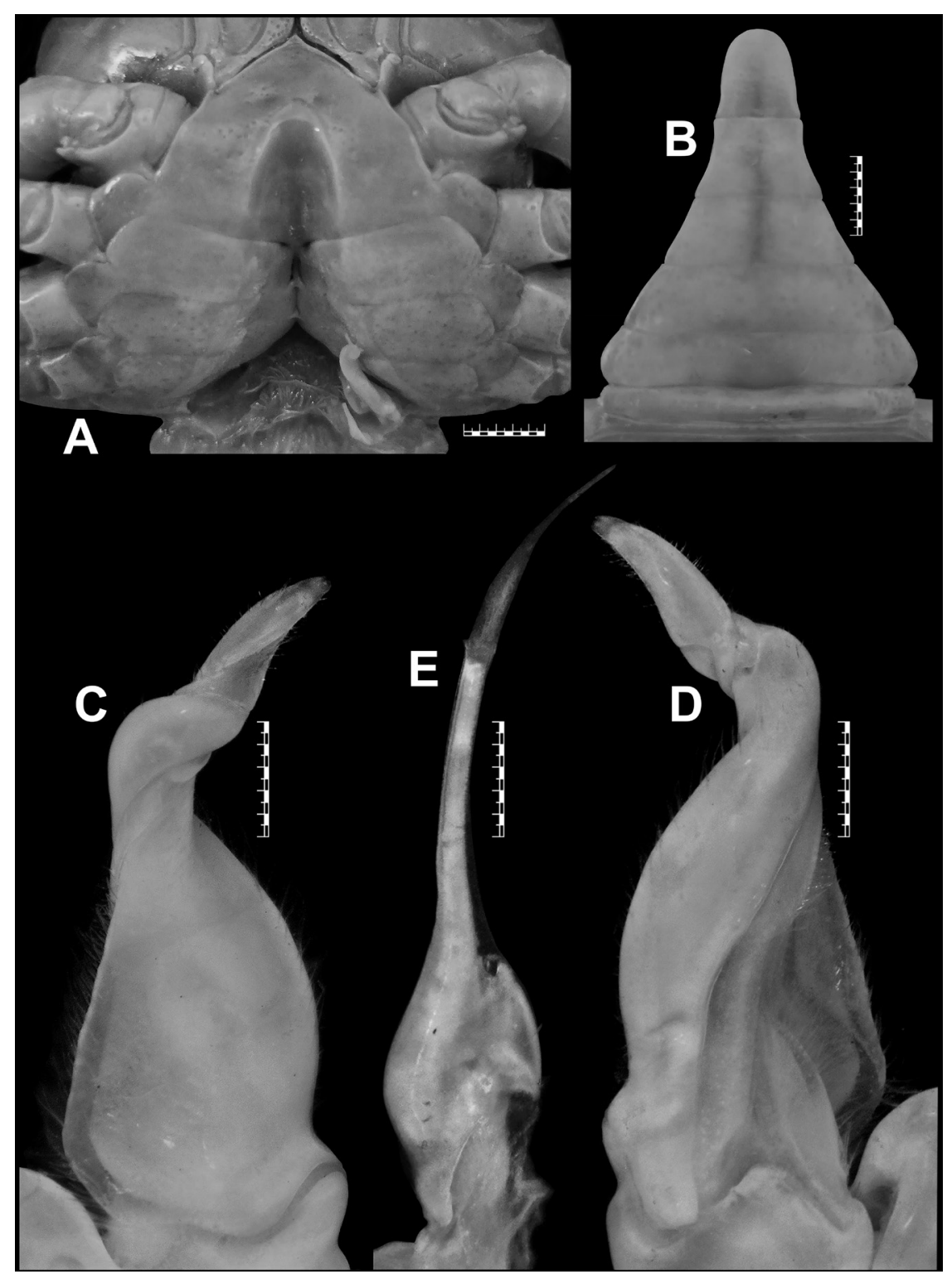

Fig. 10. Spiralothelphusa andhra sp. nov., holotype, $\widehat{\delta}(37.8 \times 30.2 \mathrm{~mm})($ ZSI-FBRC INV/2256). A. Thoracic sternites with G1 in situ (right G1 removed). B. Pleon. C. Right G1, dorsal view. D. Right G1, ventral view. E. Right G2. Scale bars: $A-B=5 \mathrm{~mm}, C-E=1 \mathrm{~mm}$. 
long, narrow, sharp inner distal major tooth and very low sub-basal granule; merus lacking subterminal spine (Figs 9A, D, 11A, C, 13). Ambulatory legs moderately stout, shorter than chelipeds (Figs 9A, $\mathrm{D}, 11 \mathrm{~A}, \mathrm{C}, 13)$. Male S1 and S2 almost fused; male S2/S3 visible as shallow medial depression, not reaching lateral margins; male S3/S4 only visible as deep submedial depressions (Figs 9D, 10A, 11D). Male sternopleonal cavity reaching to imaginary line joining anterior part of cheliped coxae (Figs 9D, 10A, 11D). Male pleon narrowly triangular, with strongly concave lateral margins; somite 6 trapezoidal, relatively broader (proximal width circa 1.7 times medial length), with concave lateral margins (Figs $7 \mathrm{~N}$, 9D, 10B). Male telson slightly longer than pleonal somite 6 , with almost straight lateral margins and broad apex (Figs 7N, 9D, 10B, 11D). G1 relatively slender, with tip gently hooked downwards; terminal segment and distal portion of subterminal segment longitudinally strongly twisted full turn, clockwise in left G1 and anticlockwise in right G1; twisted portion long, circa 0.6 times length of non-twisted portion; non-twisted portion with outer margin regularly, relatively more strongly curved, distinctly notched towards base (Figs 7L, 10C, D, 11B, E). G2 circa 1.0-1.1 times length of G1; distal segment long, circa 0.5 times length of basal segment (Fig. 10E).

\section{Etymology}

The species name, used here as a Latin noun in apposition, is after the Andhra Pradesh State of India.

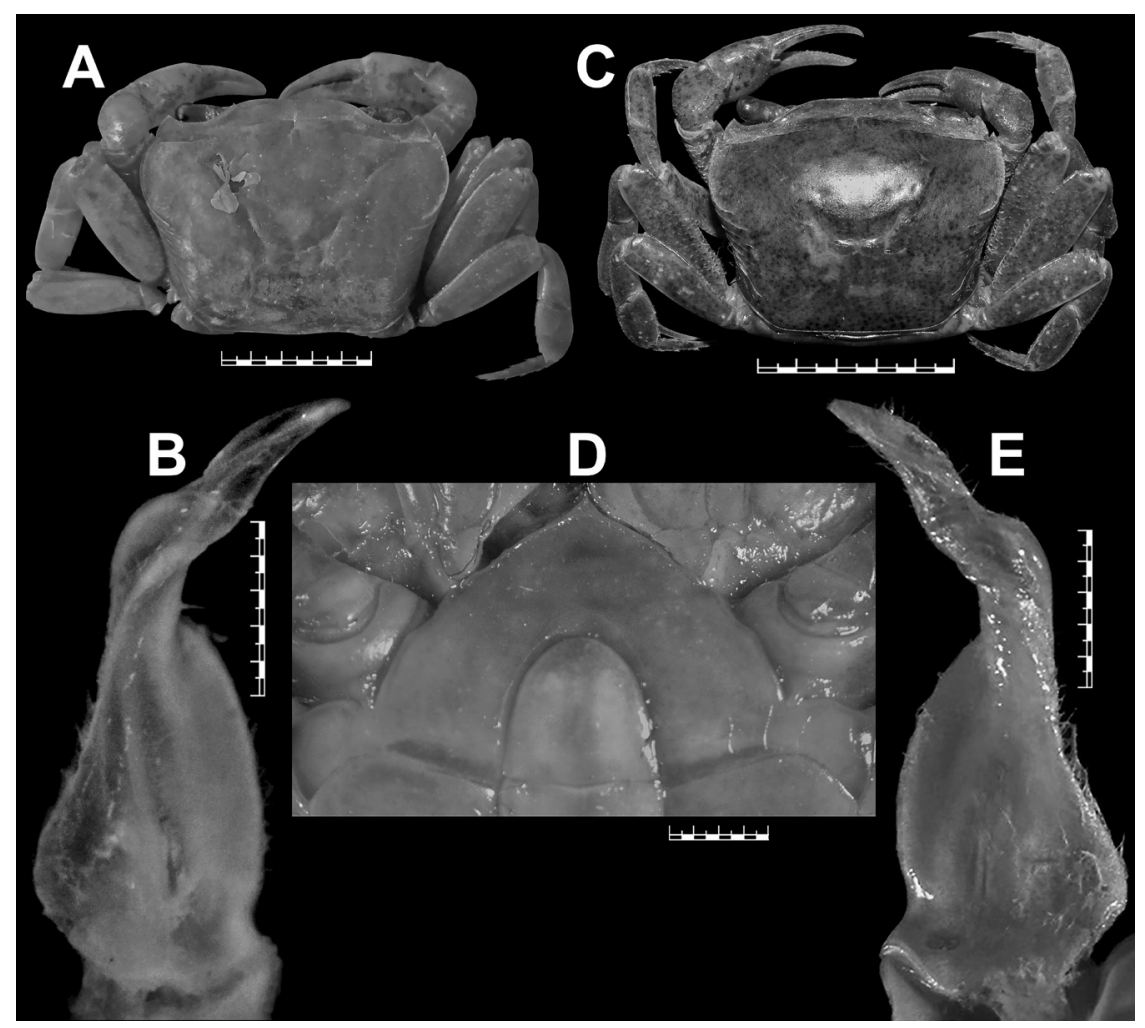

Fig. 11. Spiralothelphusa andhra sp. nov. - A-B. Paratype, $\widehat{\partial}(20.4 \times 15.8 \mathrm{~mm})($ ZSI-FBRC INV/2480). C-E. Paratype, $\widehat{\partial}(15.1 \times 11.5 \mathrm{~mm})($ ZSI-FBRC INV/2257). A, C. Entire animal, dorsal view. B. Right G1, dorsal view. D. S1-S4 with telson. E. Left G1, dorsal view. Scale bars: A, C=10 mm; D=2 mm; $\mathrm{B}, \mathrm{E}=1 \mathrm{~mm}$. 


\section{Material examined}

\section{Holotype}

INDIA - Andhra Pradesh State • $\overbrace{}^{\wedge}$ adult (CW $37.8 \mathrm{~mm}$, CL $30.2 \mathrm{~mm}, \mathrm{CH} 19.7 \mathrm{~mm}$, FW $11.9 \mathrm{~mm}$ ); Sri Potti Sriramulu Nellore District, Penna River, near Sangam Dam; $14.579^{\circ}$ N, $79.487^{\circ}$ E; alt. 56 m; 15 Dec. 2018; Boni Amin Laskar et al. leg.; GenBank: MN225969; ZSI-FBRC INV/2256.

\section{Paratypes}

INDIA - Andhra Pradesh State 1 o, subadult (CW $15.1 \mathrm{~mm}$, CL $11.5 \mathrm{~mm}$, CH $7.5 \mathrm{~mm}$, FW $5.2 \mathrm{~mm}$ ); Sri Potti Sriramulu Nellore District, Penna River, near Jonnawada; $14.477^{\circ} \mathrm{N}, 79.863^{\circ} \mathrm{E}$; alt. 19 m; 17 Dec. 2018; Boni Amin Laskar et al. leg.; GenBank: MN225972; ZSI-FBRC INV/2257 • 1 q, subadult (CW $13.3 \mathrm{~mm}$, CL $10.7 \mathrm{~mm}, \mathrm{CH} 6.8 \mathrm{~mm}, \mathrm{FW} 4.3 \mathrm{~mm}$ ); Sri Potti Sriramulu Nellore District, Penna River, near Nagarapamma Temple, Kolagatla; $14.596^{\circ} \mathrm{N}, 79.687^{\circ} \mathrm{E}$; alt. $40 \mathrm{~m} ; 15$ Dec. 2018; Boni Amin Laskar et al. leg.; GenBank: MN225970; ZSI-FBRC INV/2258 • 1 ô, subadult (CW $20.4 \mathrm{~mm}$, CL $15.8 \mathrm{~mm}, \mathrm{CH} 10.4 \mathrm{~mm}, \mathrm{FW} 7.1 \mathrm{~mm}$ ); Sri Potti Sriramulu Nellore District, Penna River, near Apparaopalem-Perumallapadu Bridge; $14.557^{\circ} \mathrm{N}, 79.625^{\circ} \mathrm{E}$; alt. $46 \mathrm{~m}$; 16 Dec. 2018; Boni Amin Laskar et al. leg.; GenBank: MN605600; ZSI-FBRC INV/2480.

\section{Description of male holotype}

Carapace broader than long $(\mathrm{CW} / \mathrm{CL}=1.3)$, deep $(\mathrm{CH} / \mathrm{CL}=0.7)$; dorsal surface strongly convex in frontal view, smooth except for epigastric cristae, postorbital cristae and posterolateral surfaces; anterolateral margins gently convex, cristate, shorter than posterolateral margins; posterolateral margins medially concave; epigastric cristae well-developed, sharp, distinctly anterior to postorbital cristae; postorbital cristae sharp, almost straight, each sloping posteriorly towards anterolateral margin; external orbital angle triangular, with outer margin circa 2 times length of inner margin; epibranchial tooth distinct, sharp, above level of postorbital cristae; postorbital region concave; branchial regions gently inflated; cervical grooves shallow, narrow, discontinuous, not reaching to level of postorbital cristae; mesogastric groove deep, narrow, short, bifurcated posteriorly; $\mathrm{H}$-shaped groove distinct; subhepatic region rugose; suborbital region rugose; pterygostomial region smooth except for few anteriorly located tubercles; supraorbital margin cristate, smooth, medially straight; suborbital margin concave, cristate, with very low tubercles, discontinuous with supraorbital margin; frontal median triangle complete, as broad as frontal margin, lateral margins not joining dorsal margin; front gently sloping downwards, subtrapezoidal; frontal margin smooth, cristate, broad $(\mathrm{FW} / \mathrm{CW}=0.3)$, medially gently concave in dorsal view; epistomal medial lobe with distinct, blunt tooth (Figs 9A-C, 13).

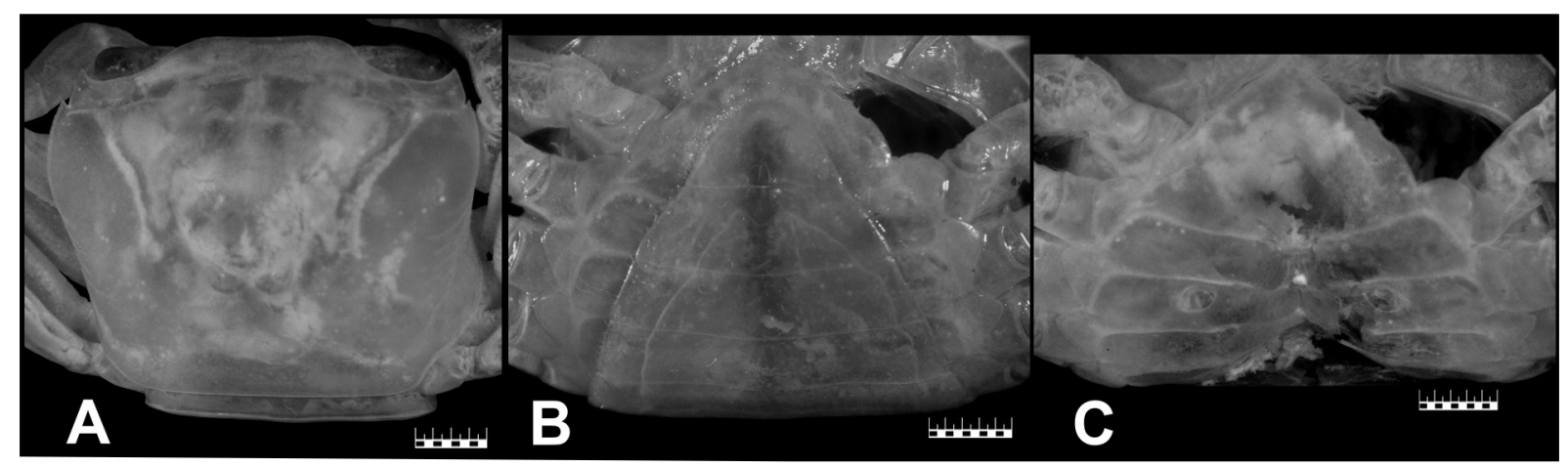

Fig. 12. Spiralothelphusa andhra sp. nov., paratype, $q(13.3 \times 10.7 \mathrm{~mm})($ ZSI-FBRC INV/2258). A. Cephalothorax, dorsal view. B. Pleon. C. Thoracic sternites showing vulvae. Scale bars: A=2 mm; $\mathrm{B}-\mathrm{C}=1 \mathrm{~mm}$. 
Eyes relatively large as compared to orbital space; eyestalk short, narrow, laterally concave; cornea large, pigmented (Fig. 9B).

Antennules long, folded in longitudinally broad fossae; antennae distally deformed but still long, equal in length to eyestalk (Fig. 9B, C). Mandibular palp 2-segmented; terminal segment bilobed. First, second maxillipeds each with long flagellum on exopod (Fig. 9C). Third maxillipeds cover most of buccal cavity when closed; ischium subrectangular, longer than broad, with deep, oblique submedial groove; merus subrectangular, broader than long, sunken; exopod moderately stout, distally narrow, longer than ischium, reaching proximal half of merus, with well-developed flagellum (Fig. 9B-D).

Cheliped generally smooth, almost equal. Chela with 15-18 blunt teeth on each finger, small gap when fingers closed; dactylus curved, slender, elongated; palm smooth, elongated; carpus slightly rugose on upper surface, gently inflated, with long, narrow, sharp inner distal major tooth and very low sub-basal granule; merus rugose, lacking subterminal spine (Figs 9A, D, 13).

Ambulatory legs moderately stout, shorter than chelipeds, P3 longest, glabrous; merus (P2-P5) lacking subdistal spine; dactylus ( $\mathrm{P} 2-\mathrm{P} 5)$ gently recurved, subequal in length to propodus, with few distinct, sharp chitinous spines on margins (Figs 9A, D, 13).

Thoracic sternites smooth, glabrous, punctate; $\mathrm{S} 1$ and $\mathrm{S} 2$ almost fused; $\mathrm{S} 2 / \mathrm{S} 3$ visible as shallow medial depression, not reaching lateral margins; S3/S4 only visible as deep submedial depressions; S4/S5, S5/ S6, S6/S7 deep, narrow, medially interrupted; S7/S8 shallow, narrow, with medial transverse ridge, interrupting longitudinal groove (Figs 9D, 10A). Pleonal locking mechanism with prominent tubercle on submedial part of S5 (Fig. 10A). Sternopleonal cavity deep, long, reaching to imaginary line joining anterior part of cheliped coxae (Figs 9D, 10A).

Pleon narrowly triangular, with strongly concave lateral margins; somites 1, 2 narrower than somite 3; somite 3 broadest, with strongly convex lateral margins; somites 4, 5 trapezoidal, with straight lateral

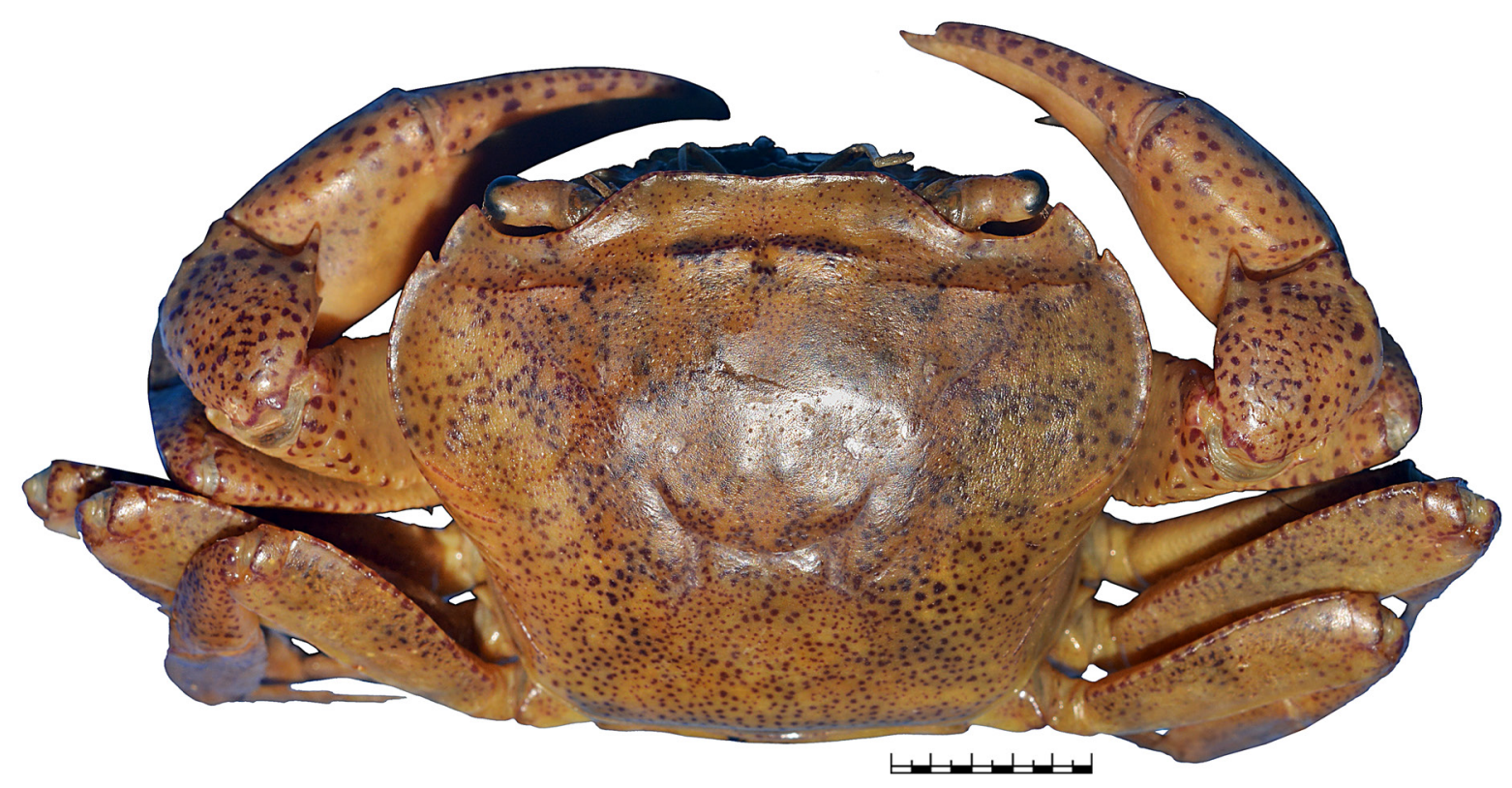

Fig. 13. Spiralothelphusa andhra sp. nov., holotype, $\widehat{\partial}(37.8 \times 30.2 \mathrm{~mm})($ ZSI-FBRC INV/2256), colour of dorsal surface when freshly preserved. Scale bar $=10 \mathrm{~mm}$. 
margins; somite 6 trapezoidal, broader than long (proximal width circa 1.7 times medial length), distinctly longer than preceding somites, with concave lateral margins (Figs 7N, 9D, 10B). Telson slightly longer than pleonal somite 6 , longer than broad (medial length circa 1.2 times proximal width), with almost straight lateral margins and broad apex (Figs 7N, 9D, 10B).

G1 relatively slender, with tip gently hooked downwards, not reaching S5/S6; terminal segment and distal portion of subterminal segment longitudinally strongly twisted full turn, clockwise in left G1 and anticlockwise in right G1; twisted portion long, circa 0.6 times length of non-twisted portion; nontwisted portion with outer margin regularly but strongly curved, distinctly notched towards base; groove for G2 lateral (Figs 7L, 10A, C-D). G2 circa 1.0 times length of G1; distal segment long, circa 0.5 times length of basal segment (Fig. 10E).

\section{Remarks}

Spiralothelphusa andhra sp. nov. is unique among congeners due to the strongly concave (distinctly notched) outer margin of the G1 near the base (Figs 7L, 10C-D, 11B, E). In the G1 structure, S. andhra sp. nov. is most similar to $S$. wuellerstorfi in that both species possess a G1 with strongly, longitudinally twisted terminal segment and distal portion of the subterminal segment (fully turned clockwise in the left G1 and anticlockwise in the right G1), and the tip of the G1 in them is gently hooked downwards (Figs 4B-C, 6A-C, 7B, K-L, 10C-D, 11B, E). Spiralothelphusa andhra sp. nov., however, is separated from $S$. wuellerstorfi by the almost straight lateral margins of the male telson (Figs 7N, 9D, 10B, 11D) (vs male telson with the concave lateral margins; Figs 3C, 7M), and the regularly, relatively more strongly curved outer margin of the G1 non-twisted portion, which is distinctly notched towards base (Figs 7L, 10C-D, 11B, E) (vs G1 non-twisted portion with sharply, relatively less strongly curved outer margin, which is straight towards base; Figs 4B-C, 6A-C, 7B, K).

The male paratypes (ZSI-FBRC INV/2257, 2480) of $S$. andhra sp. nov. are subadults but share most of the features of the carapace (Fig. 11A, C-D) with the male holotype. Their G1s possess the characteristically strongly concave outer margin towards the base (Fig. 11B, E). The following notable differences, however, are observed between the male paratypes and the male holotype. The postorbital cristae are distinctly curved in the larger male paratype (ZSI-FBRC INV/2480), i.e., each postorbital crista slopes posteriorly towards the postorbital region and then anteriorly towards the anterolateral margin (Fig. 11A) (vs almost straight postorbital cristae, each sloping posteriorly towards the anterolateral margin in the male holotype; Figs 9A, 13). This intraspecific variation raises doubt on the consistency or reliability of the shape of the postorbital cristae as one of the key characters for separating the species of Spiralothelphusa as used by Pati \& Sudha Devi (2015). The smaller male paratype (ZSI-FBRC INV/2257) has a relatively broader telson, i.e., the medial length of the telson is almost equal to its proximal width (Fig. 11D) (vs relatively longer telson, with the medial length measuring about 1.2 times the proximal width in the male holotype; Figs 7N, 9D, 10B).

The only female paratype (ZSI-FBRC INV/2258) of S. andhra sp. nov. is a subadult, which is similar to the male holotype in most of the non-sexual character states (Fig. 12A). Its pleonal somites and telson are subtriangular, which cover the thoracic sternum except for S1-S3 and lateral parts when closed (Fig. 12B). The pleonal somite 1 is the shortest; pleonal somites $2-5$ are progressively longer; pleonal somite 6 is the longest, broader than long, as long as the telson, with the gently convex lateral margins (Fig. 12B). The telson is subtriangular, broader than long, with almost straight lateral margins (Fig. 12B). The vulvae on S6 in the subadult female paratype are positioned apart from each other $(\mathrm{VD} / \mathrm{SW}=$ circa 0.3 ), each opens ventrally, subovate, large (occupying circa 0.5 times length of S6), positioned some distance from S5/S6, and surrounded by a raised, broad rim (Fig. 12C). 


\section{Colour in life}

Carapace, chelipeds and ambulatory legs all are brown with numerous purplish-brown spots on the dorsal surface (Fig. 13). Their ventral surfaces are paler and spotless.

\section{Ecological notes}

Spiralothelphusa andhra sp. nov. was found among partly submerged long grasses (mostly Typha angustata Bory \& Chaub., and Saccharum spontaneum Linnaeus) in the Penna river between the Somasila Reservoir and Nellore town of the Sri Potti Sriramulu Nellore District, Andhra Pradesh (Fig. 14A-B). Crabs were collected underneath pebbles in shallow water (depth $<1 \mathrm{~m}$ ) by scooping with a D-shaped aquatic net (Fig. 14A-B).

\section{Geographical distribution}

Spiralothelphusa andhra sp. nov. is known only from the lower reaches of the Penna River Basin in the Andhra Pradesh State, South India (Fig. 8).

\section{Illustrated key to the species of Spiralothelphusa Bott, 1968}

1. G1 with longitudinally less strongly twisted (half turn) terminal segment and distal portion of subterminal segment (Fig. 7A)

- G1 with longitudinally more strongly twisted (full turn) terminal segment and distal portion of

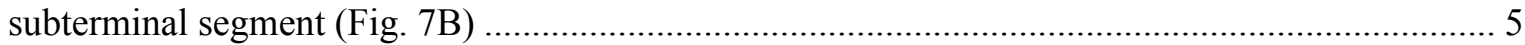

2. G1 tip gently curved upwards (Fig. 7C); G1 non-twisted portion with gently curved outer margin (Fig. 7C). Spiralothelphusa hydrodroma (Herbst, 1794)

- G1 tip almost straight to gently hooked downwards (Fig. 7D-F); G1 non-twisted portion with strongly or sharply curved outer margin (Fig. 7D-F)...

3. Male telson with gently concave lateral margins (Fig. 7G); G1 non-twisted portion with sharply curved outer margin (Fig. 7D) ..... Spiralothelphusa senex (Fabricius, 1798)

- Male telson with straight lateral margins (Fig. 7H-I); G1 non-twisted portion with regularly curved outer margin (Fig. 7E-F) .....

4. Male pleonal somite 6 relatively narrower, proximal width circa 1.3 times medial length (Fig. $7 \mathrm{H})$; male telson equal in length to male pleonal somite 6 (Fig. 7H); G1 non-twisted portion with relatively less strongly convex outer margin (Fig. 7E). Spiralothelphusa fernandoi $\mathrm{Ng}, 1994$

- Male pleonal somite 6 relatively broader, proximal width circa 1.6 times medial length (Fig. 7I); male telson slightly longer than male pleonal somite 6 (Fig. 7I); G1 non-twisted portion with relatively more strongly convex, hump-like outer margin (Fig. 7F)

5. G1 relatively stout, with tip strongly curved upwards (Fig. 7J)

- G1 relatively slender, with tip gently hooked downwards (Fig. 7K-L).....

6. Male telson with concave lateral margins (Fig. 7M); G1 non-twisted portion with outer margin sharply, relatively less strongly curved and straight towards base (Fig. 7K)

Spiralothelphusa wuellerstorfi (Heller, 1862)

- Male telson with almost straight lateral margins (Fig. 7N); G1 non-twisted portion with outer margin regularly, relatively more strongly curved and distinctly notched towards base (Fig. 7L) 


\section{Discussion}

Spiralothelphusa andhra sp. nov. and S. wuellerstorfi both belong to the monophyletic "Spiralothelphusa clade" (Fig. 2). The distinct clades formed by them corroborate their morphological separation (Fig. 2). All the sequences of $S$. andhra sp. nov. (MN225969, MN225970, MN225972, and MN605600) have been assigned to $S$. wuellerstorfi in the GenBank probably because of their similarity in the G1 structure. Spiralothelphusa andhra sp. nov. shows a low intraspecific variation as regards to mt COI DNA (p-distance $=0.2-0.3 \%$ ) (Table 2). Spiralothelphusa andhra sp. nov. differs from S. wuellerstorfi by a genetic distance of 7.3-7.6\%, which is much higher than the minimum interspecific variation $(\mathrm{p}$-distance $=3.4 \%)($ Table 2). Spiralothelphusa andhra sp. nov. instead showed the phylogenetic sister relationship with a hitherto unknown species of Spiralothelphusa from the Telangana State (Fig. 2), with a genetic divergence of 3.6-3.7\% (Table 2). The sequence of this undescribed species (MN605608) was also assigned to $S$. wuellerstor $f$ in the GenBank. We decline to describe the species from Telangana here because the material in hand is that of females. The species of Spiralothelphusa from Telangana might be morphologically related to the specimens from Maharashtra as their respective localities are some $235 \mathrm{~km}$ apart. No molecular data, however, is available for Spiralothelphusa species from Maharashtra. Fresh collections from both regions are thus needed.

Furthermore, a sequence (MG924933) previously assigned to Oziotelphusa hippocastanum (Müller, 1887) in the GenBank is nested within the "Spiralothelphusa clade" (Fig. 2). Oziotelphusa hippocastanum is a Sri Lankan species, which bears no similarity to any Spiralothelphusa species in the G1 structure (Ng \& Tay 2001; Bahir \& Yeo 2005). We could not locate the material (with GenBank accession number MG924933) from an unknown locality in India for morphological comparison, but we assume the sequence could belong to Spiralothelphusa cf. wuellerstorfi because of its genetic distance (2\%) from $S$. wuellerstorfi is lower than the minimum interspecific variation (p-distance $=3.4 \%$ ) (Table 2$)$. Naser et al. (2018) also noted that the genetic divergence of up to about $2 \%$ can be accounted for the intraspecific variation in some species of the gecarcinucid genus Austrothelphusa Bott, 1969. In the contrast, some freshwater crab species of Geothelphusa Stimpson, 1858, the second largest genus of

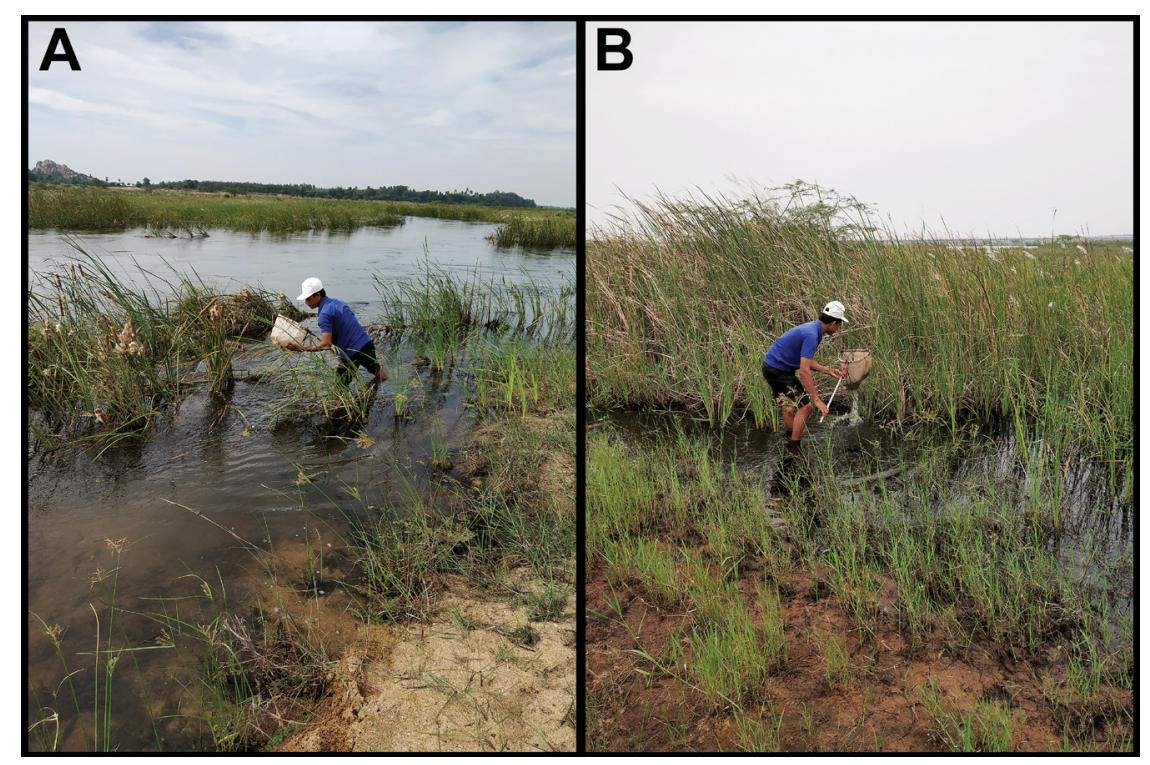

Fig. 14. Habitats of Spiralothelphusa andhra sp. nov. in the Penna River, near Apparaopalem-Perumallapadu Bridge of Sri Potti Sriramulu Nellore District, Andhra Pradesh, South India. A. Habitat dominated with Typha angustata Bory \& Chaub. B. Habitat dominated with Saccharum spontaneum Linnaeus. 
the family Potamidae Ortmann, 1896, can be separated based on a genetic distance of as low as $1.48 \%$ (cf. Shih et al. 2011; Shy et al. 2014). The extent of intraspecific variation in mt COI DNA is not known for most species of Spiralothelphusa. In this situation, the sequence (MG924933) might also be originated from a hitherto unknown species, or from a known species other than $S$. wuellerstorfi, e.g., $S$. hydrodroma and $S$. senex. No molecular data, however, is readily available for $S$. hydrodroma and $S$. senex mainly because of their unresolved taxonomy. The structures of the male telson and the male first gonopod are unknown in the lectotype of $S$. hydrodroma (type species). The provisional identity of S. hydrodroma was based on a topotype male only (see $\mathrm{Ng} \&$ Tay 2001). The lectotype of S. hydrodroma was recognized by $\mathrm{Ng} \&$ Tay (2001), who referred to the larger male syntype from "Traquebar" illustrated in Sakai (1999). The type locality of S. hydrodroma, "Tranquebar" is a historical name for the presentday Tharangambadi of the Tamil Nadu State on the southeast coast of India. Spiralothelphusa senex also possibly originated from "Tranquebar", which has minor differences from S. hydrodroma in gonopod structure only (Ng \& Tay 2001).

No clear differences in the external morphology can be observed between Spiralothelphusa and Oziotelphusa; the presence or absence of the longitudinal twisting in the G1 is the only reliable character for distinguishing them ( $\mathrm{Ng} \&$ Tay 2001). According to Bahir \& Yeo (2005), the G1s of Spiralothelphusa species bear a remarkable resemblance with that of Oziotelphusa species, albeit their different degrees of longitudinal twisting (half to full turn). They have also indicated that the current definition of Spiralothelphusa is likely to change if any species with a less obvious longitudinally twisting of the G1 is discovered in the future. Beenaerts et al. (2010), however, showed that Spiralothelphusa is a monophyletic clade but nested within the paraphyletic Oziotelphusa. More robust phylogenetic and morphological analyses are currently required for Spiralothelphusa and Oziotelphusa, involving most species and different genes.

\section{Acknowledgements}

The authors thank the Director of the Zoological Survey of India, Kolkata for research facilities and encouragement. We thank Dr Boni Amin Laskar and his team (ZSI-FBRC) for kindly collecting the material of the new species. The photographs were taken by Dr Martin Schwentner (curator of Crustacean collections in NHMW) (Figs 3-5), Dr Peter Ng (ZRC) (Fig. 6A), and Mr. Harikumar Adimalla (ZSIFBRC) (Fig. 14A-B); all of them are sincerely acknowledged. Many thanks to Dr Peter Ng (ZRC) for the permission to reproduce some images (Fig. 7C-E, G-H, J) from $\mathrm{Ng} \&$ Tay (2001). We also thank Dr Peter Ng (ZRC) for providing some literature and his notes. Figure 7I was from Pati \& Sudha Devi (2015) published in Zootaxa by the Magnolia Press, reproduced herein by the first author (SKP) with the right to use. Dr Peter Dworschak (former curator of Crustacea collections in NHMW) is thanked for providing information on the syntypic material of Spiralothelphusa wuellerstorfi, while Dr K.A. Subramanian (Zoological Survey of India, Southern Regional Centre, Chennai, India) is acknowledged for the information on the recent expedition to the Nicobar Islands by the Zoological Survey of India. We are thankful to Dr K.P. Dinesh (ZSI-WRC) for help in constructing the phylogenetic tree. We gratefully acknowledge two anonymous reviewers for their valuable comments and suggestions.

\section{Conflicts of interest}

The authors declare no conflicts of interest.

\section{References}

Bahir M.M. \& Yeo D.C.J. 2005. A revision of the genus Oziotelphusa Müller, 1887 (Crustacea: Decapoda: Parathelphusidae), with descriptions of eight new species. Raffles Bulletin of Zoology, Supplement 12: $77-120$. 
Bahir M.M., Ng P.K.L., Crandall K. \& Pethiyagoda R. 2005. A conservation assessment of the freshwater crabs of Sri Lanka. Raffles Bulletin of Zoology, Supplement 12: 121-126.

Beenaerts N., Pethiyagoda R., Ng P.K.L., Yeo D.C.J., Bex G.J., Bahir M.M. \& Artois T. 2010. Phylogenetic diversity of Sri Lankan freshwater crabs and its implications for conservation. Molecular Ecology 19 (1): 183-196. https://doi.org/10.1111/j.1365-294X.2009.04439.x

Bott R. 1968. Parathelphusiden aus Hinterindien (Crustacea, Decapoda, Parathelphusidae). Senckenbergiana biologica 49 (5): 403-422.

Bott R. 1970. Die Süßwasserkrabben von Europa, Asien, Australien und ihre Stammesgeschichte. Eine Revision der Potamoidea und Parathelphusoidea (Crustacea, Decapoda). Abhandlungen der Senckenbergischen Naturforschenden Gesellschaft 526: 1-338.

Bürger O. 1894. Beiträge zur Kenntniss der Gattung Telphusa. Zoologische Jahrbücher. Abteilung für Systematik, Geographie und Biologie der Thiere 8 (1): 1-7.

Cumberlidge N. 1997. The African and Madagascan freshwater crabs in the Museum of Natural History, Vienna (Crustacea: Decapoda: Brachyura: Potamoidea). Annalen des Naturhistorischen Museums in Wien 99B: 571-589.

Davie P.J.F., Guinot D. \& Ng P.K.L. 2015. Anatomy and functional morphology of Brachyura. In: Castro P., Davie P.J.F., Guinot D., Schram F.R. \& von Vaupel Klein J.C. (eds) Treatise on Zoology Anatomy, Taxonomy, Biology. The Crustacea. Volume 9 (Part C-I). Decapoda: Brachyura (Part 1): 11-163. Brill, Leiden, the Netherlands. https://doi.org/10.1163/9789004190832_004

De Man J.G. 1898. Viaggio di Leonardo Fea in Birmanica e regioni vicine. LXXXI. - Note sur quelques espèces des genres Parathelphusa H.M.E. et Potamon Sav., recueillies par M. Leonardo Fea pendant son voyage en Birmanie. Annali del Museo civico di Storia naturale di Genova, Series 219 (39): 384-440.

Dev Roy M.K. \& Nandi N.C. 2012. Brachyuran crabs (Crustacea). In: The Director (ed.) Fauna of Andaman and Nicobar Islands, State Fauna Series 19 (Part 1): 185-236. Zoological Survey of India, Kolkata, India.

Edler D., Klein J., Antonelli A. \& Silvestro D. 2021. raxmlGUI 2.0: A graphical interface and toolkit for phylogenetic analyses using RAxML. Methods in Ecology and Evolution 12 (2): 373-377. https://doi.org/10.1111/2041-210X.13512

Fernando C.H. 1960. The Ceylonese Freshwater Crabs (Potamonidae). Ceylon Journal of Science (Biological Science) 3 (2): 191-222.

Guinot D., Tavares M. \& Castro P. 2013. Significance of the sexual openings and supplementary structures on the phylogeny of brachyuran crabs (Crustacea, Decapoda, Brachyura), with new nomina for higher-ranked podotreme taxa. Zootaxa 3665 (1): 1-414. https://doi.org/10.11646/zootaxa.3665.1.1

Heller C. 1862. Neue Crustaceen, gesammelt während der Weltumseglung der k. k. Fregatte Novara. Zweiter vorläufiger Bericht. Verhandllungen der kaiserlich-königlichen zoologisch-botanischen Gesellschaft in Wien 12: 519-528.

Heller C. 1865. Crustaceen. In: Reise der österreichischen Fregatte Novara um die Erde in den Jahren 1857, 1858, 1859 unter den Befehlen des Commodore B. von Wüllerstorf-Urbair. Zoologischer Theil. Zweiter Band. III. Abtheilung: 1-280. Kaiserlich-Königliche Hof- und Staatsdruckerei, in Commission bei Karl Gerold's Sohn, Vienna.

Henderson J.R. 1893. A contribution to Indian carcinology. Transactions of the Linnean Society of London, Series 25 (10): 325-458. 
ICZN (International Commission on Zoological Nomenclature) 1999. International Code of Zoological Nomenclature. Fourth edition. The International Trust for Zoological Nomenclature, The Natural History Museum, London.

Kumar S., Stecher G., Li M., Knyaz C. \& Tamura K. 2018. MEGA X: Molecular Evolutionary Genetics Analysis across Computing Platforms. Molecular Biology and Evolution 35 (6): 1547-1549. https://doi.org/10.1093/molbev/msy096

Milne Edwards H. 1853. Mémoire sur la famille des Ocypodiens. Annales des Sciences naturelles, Zoologie, Série 3 20: 163-228.

Milne-Edwards A. 1869. Révision du genre Thelphuse et description de quelques espèces nouvelles. Nouvelles Archives du Muséum d'histoire naturelle de Paris 5: 161-191.

Montesanto G. 2015. A fast GNU method to draw accurate scientific illustrations for taxonomy. ZooKeys 515: 191-206. https://doi.org/10.3897/zookeys.515.9459

Naser M.D., Davie P.J.F. \& Waltham N.J. 2018. Redescription of Austrothelphusa wasselli (Bishop, 1963) (Crustacea: Brachyura: Gecarcinucidae), and designation of a new species from the Gilbert River, north Queensland, Australia. Zootaxa 4369 (1): 109-127. https://doi.org/10.11646/zootaxa.4369.1.6

Ng P.K.L. 1994. A note on the freshwater crabs of the genus Spiralothelphusa Bott, 1968 (Crustacea: Decapoda: Brachyura: Parathelphusidae), with description of a new species from Sri Lanka. Journal of South Asian natural History 1 (1): 27-30.

Ng P.K.L. \& Tay F.W.M. 2001. The freshwater crabs of Sri Lanka (Decapoda: Brachyura: Parathelphusidae). Zeylanica 6 (2): 113-199.

Ng P.K.L., Guinot D. \& Davie P.J.F. 2008. Systema Brachyurorum: Part I. An annotated checklist of extant brachyuran crabs of the world. Raffles Bulletin of Zoology, Supplement 17: 1-286.

Ortmann A.E. 1893. Die Decapoden-Krebse des Strassburger Museums, mit besonderer Berücksichtigung der von Herrn Dr. Döderlein bei Japan und bei den Liu-Kiu-Inseln gesammelten und zur Zeit im Strassburger Museum aufbewahrten Formen. Zoologische Jahrbücher, Abteilung für Systematik, Geographie und Biologie der Thiere 7 (3): 411-494.

Ortmann A.E. 1897. Carcinologische Studien. Zoologische Jahrbücher, Abteilung für Systematik, Geographie und Biologie der Thiere 10 (3): 258-372.

Pati S.K. 2021. Two new species of freshwater crabs of the genus Potamiscus Alcock, 1909 (Brachyura: Potamidae) from Nagaland, northeastern India. Nauplius 29: e2021006. https://doi.org/10.1590/2358-2936e2021006

Pati S.K. \& Mandal S. 2021. Crustacea: Decapoda: Brachyura (Freshwater Crabs). In: Chandra K., Jaiswal D., Raghunathan C., Jadhav S.S. \& Karuthapandi M. (eds) Current Status of Faunal Diversity in Telangana: 113-118. The Director, Zoological Survey of India, Kolkata, India.

Pati S.K. \& Sharma R.M. 2014. Freshwater crabs (Crustacea: Decapoda: Brachyura: Gecarcinucidae) in the collection of the Western Regional Centre, Pune. Records of the Zoological Survey of India, Occasional Paper 363: 1-44.

Pati S.K. \& Sudha Devi A.R. 2015. Spiralothelphusa gibberosa, a new freshwater crab (Brachyura: Gecarcinucidae) from Thrissur district, Kerala, India. Zootaxa 3963 (3): 416-424.

https://doi.org/10.11646/zootaxa.3963.3.5 
Pati S.K. \& Thackeray T. 2018. The freshwater crab genera Ghatiana Pati \& Sharma, Gubernatoriana Bott, and Inglethelphusa Bott (Crustacea: Decapoda: Brachyura: Gecarcinucidae) revisited, with descriptions of a new genus and eleven new species. Zootaxa 4440 (1): 1-73.

https://doi.org/10.11646/zootaxa.4440.1.1

Pati S.K. \& Vargila F. 2019. A new species of the freshwater crab genus Oziotelphusa Müller, 1887 from Tamil Nadu, India (Crustacea, Decapoda, Brachyura, Gecarcinucidae). Spixiana 42 (2): 203-216.

Rajesh L., Raj S., Pati S.K. \& Kumar A.B. 2017. The freshwater crabs (Decapoda: Brachyura) of Kerala, India. Journal of Aquatic Biology \& Fisheries 5: 132-153.

Rathbun M.J. 1904. Les crabes d'eau douce (Potamonidae). Nouvelles Archives du Muséum d'histoire naturelle, Paris, Série 4 6: 225-312.

Sakai K. 1999. J.F.W. Herbst-collection of decapod Crustacea of the Berlin Zoological Museum, with remarks on certain species. Naturalists, Publications of Tokushima Biological Laboratory, Shikoku University 6: 1-45.

Scherzer K. 1861. Narrative of the Circumnavigation of the Globe by the Austrian Frigate Novara, (Commodore B. Von Wullerstorf-Urbair,) Undertaken by Order of the Imperial Government, in the Years of 1857, 1858, \& 1859, under the Immediate Auspices of His I. and R. Highness the Archduke Ferdinand Maximilian, Commander-in-Chief of the Austrian Navy. Vol. 1. Saunders, Otley \& Co., London.

Shih H.-T., Ng P.K.L., Naruse T., Shokita S. \& Liu M.-Y. 2011. Pleistocene speciation of freshwater crabs (Crustacea: Potamidae: Geothelphusa) from northern Taiwan and southern Ryukyus, as revealed by phylogenetic relationships. Zoologischer Anzeiger 250 (4): 457-471.

https://doi.org/10.1016/j.jcz.2011.07.004

Shy J.-Y., Shih H.-T. \& Mao J.-J. 2014. Description of a new montane freshwater crab (Crustacea: Potamidae: Geothelphusa) from northern Taiwan. Zootaxa 3869 (5): 565-572.

https://doi.org/10.11646/zootaxa.3869.5.6

Wood-Mason J. 1871. Contribution to Indian Carcinology. — On Indian and Malayan Telphusidae, Part-I. Journal of the Asiatic Society of Bengal, Part II (Physical Science) 40 (No. 3): 201-207.

Manuscript received: 26 June 2021

Manuscript accepted: 5 October 2021

Published on: 25 February 2022

Topic editor: Rudy C.A.M. Jocqué

Desk editor: Kristien Vrancken

Printed versions of all papers are also deposited in the libraries of the institutes that are members of the EJT consortium: Muséum national d'histoire naturelle, Paris, France; Meise Botanic Garden, Belgium; Royal Museum for Central Africa, Tervuren, Belgium; Royal Belgian Institute of Natural Sciences, Brussels, Belgium; Natural History Museum of Denmark, Copenhagen, Denmark; Naturalis Biodiversity Center, Leiden, the Netherlands; Museo Nacional de Ciencias Naturales-CSIC, Madrid, Spain; Real Jardín Botánico de Madrid CSIC, Spain; Zoological Research Museum Alexander Koenig, Bonn, Germany; National Museum, Prague, Czech Republic. 